\title{
Species-Level Spatio-Temporal Dynamics of Cyanobacteria in a Hard-Water Temperate Lake in the Southern Baltics
}

\author{
Ebuka Canisius Nwosu ${ }^{1 *}$, Patricia Roeser ${ }^{2}$, Sizhong Yang ${ }^{1}$, Sylvia Pinkerneil ${ }^{3}$, \\ Lars Ganzert ${ }^{1}$, Elke Dittmann ${ }^{4}$, Achim Brauer ${ }^{3,5}$, Dirk Wagner ${ }^{1,5}$ and Susanne Liebner ${ }^{1,4}$ \\ ${ }^{1}$ Section Geomicrobiology, GFZ German Research Centre for Geosciences, Potsdam, Germany, ${ }^{2}$ Marine Geology Section, \\ Leibniz Institute for Baltic Sea Research (IOW), Rostock, Germany, ${ }^{3}$ Section Climate Dynamics and Landscape Evolution, \\ GFZ German Research Centre for Geosciences, Potsdam, Germany, ${ }^{4}$ Institute of Biochemistry and Biology, University of \\ Potsdam, Potsdam, Germany, ${ }^{5}$ Institute of Geosciences, University of Potsdam, Potsdam, Germany
}

OPEN ACCESS

Edited by:

Rehab El-Shehawy,

Stockholm University, Sweden

Reviewed by:

Elena Gorokhova,

Stockholm University, Sweden

Björn Brindefalk,

Stockholm University, Sweden

*Correspondence:

Ebuka Canisius Nwosu

enwosu@gfz-potsdam.de orcid.org/0000-0002-0715-9597

Specialty section:

This article was submitted to

Aquatic Microbiology,

a section of the journal

Frontiers in Microbiology

Received: 19 August 2021 Accepted: 06 October 2021 Published: 29 October 2021

Citation:

Nwosu EC, Roeser P, Yang S, Pinkerneil S, Ganzert L, Dittmann E, Brauer A, Wagner D and Liebner S (2021) Species-Level

Spatio-Temporal Dynamics of Cyanobacteria in a Hard-Water

Temperate Lake in the Southern

Baltics. Front. Microbiol. 12:761259. doi: 10.3389/fmicb.2021.761259
Cyanobacteria are important primary producers in temperate freshwater ecosystems. However, studies on the seasonal and spatial distribution of cyanobacteria in deep lakes based on high-throughput DNA sequencing are still rare. In this study, we combined monthly water sampling and monitoring in 2019, amplicon sequence variants analysis (ASVs; a proxy for different species) and quantitative PCR targeting overall cyanobacteria abundance to describe the seasonal and spatial dynamics of cyanobacteria in the deep hard-water oligo-mesotrophic Lake Tiefer See, NE Germany. We observed significant seasonal variation in the cyanobacterial community composition $(p<0.05)$ in the epiand metalimnion layers, but not in the hypolimnion. In winter-when the water column is mixed-picocyanobacteria (Synechococcus and Cyanobium) were dominant. With the onset of stratification in late spring, we observed potential niche specialization and coexistence among the cyanobacteria taxa driven mainly by light and nutrient dynamics. Specifically, ASVs assigned to picocyanobacteria and the genus Planktothrix were the main contributors to the formation of deep chlorophyll maxima along a light gradient. While Synechococcus and different Cyanobium ASVs were abundant in the epilimnion up to the base of the euphotic zone from spring to fall, Planktothrix mainly occurred in the metalimnetic layer below the euphotic zone where also overall cyanobacteria abundance was highest in summer. Our data revealed two potentially psychrotolerant (cold-adapted) Cyanobium species that appear to cope well under conditions of lower hypolimnetic water temperature and light as well as increasing sediment-released phosphate in the deeper waters in summer. The potential cold-adapted Cyanobium species were also dominant throughout the water column in fall and winter. Furthermore, Snowella and Microcystis-related ASVs were abundant in the water column during the onset of fall turnover. Altogether, these findings suggest previously unascertained and considerable spatiotemporal changes in the community of cyanobacteria on the species level especially within the genus Cyanobium in deep hard-water temperate lakes.

Keywords: Cyanobium, picocyanobacteria diversity, amplicon sequencing, lake monitoring, ecological succession, lake stratification, psychrotolerant 


\section{INTRODUCTION}

Photosynthetic microorganisms function as the basis of food chains in aquatic environments and are thus of importance to the ecosystem and to humans. Cyanobacteria have been studied extensively as an important contributor to global primary production in oceans and lakes (Mazard et al., 2016; Soule and Garcia-Pichel, 2019). In temperate climate, most lakes are stratified usually beginning in late spring into the epilimnion (warmer upper water column), the hypolimnion (dark and cold deep water), and the metalimnion, a transition layer between the warmer and colder layers. Because of the fast changes in temperature and increasing density within the metalimnion, this layer acts as a physical barrier between the epi- and hypolimnion (Boehrer and Schultze, 2008). One of the expected effects of increasing global temperatures and climate change on temperate lakes is that prolonged periods of stratification may extend and thus change the community structure of cyanobacteria (diversity and composition) inhabiting these lakes (Salmaso et al., 2015; Visser et al., 2016; Huisman et al., 2018).

Molecular-based techniques have been employed in studying seasonal changes in lacustrine bacterial communities (e.g., Allgaier and Grossart, 2006; Ivanikova et al., 2007) and the interactions between bacteria and phytoplankton in lakes (Nitin Parulekar et al., 2017; Schweitzer-Natan et al., 2019). Studies on lake bacterioplankton seasonality based on 16S rRNA gene sequencing have for instance brought attention to the sources and dangers of eutrophication via nutrient loading (e.g., Kong et al., 2019). Furthermore, advances in sequencing techniques with improved taxonomic resolution have provided additional understanding to the seasonal succession of bacterioplankton communities in the upper waters of lakes (Okazaki and Nakano, 2016; Diao et al., 2017; Salmaso et al., 2018). For example, in Lake Vechten (Netherlands; max. depth $11 \mathrm{~m}$ ), highthroughput sequencing of every meter in the water column revealed changes in bacteria community composition to be driven by lake oxygenation and sulphidic conditions (Diao et al., 2017). Other factors driving cyanobacteria seasonality and niche differentiation include light intensity and differences in cyanobacteria accessory pigments which influence their adaptation to spectral light quality (Pick and Agbeti, 1991; Vörös et al., 1998; Callieri et al., 2012b). Research on seasonality and succession of phytoplankton in lakes either via cell counts or the creation of $16 \mathrm{~S}$ rRNA sequence clone libraries approaches have helped in the identification of important taxonomic groups within the phylum Cyanobacteria (Albrecht et al., 2017; Butts and Carrick, 2017). An advantage of using high-throughput sequencing techniques is the possibility of a more holistic estimation, especially of small $(0.2-2 \mu \mathrm{m})$ picocyanobacteria (e.g., Synechococcus sp. and Cyanobium sp.). Members of this group are often not reliably identified and differentiated by microscopy (Callieri et al., 2012b; Salmaso et al., 2018). Except for Salmaso et al. (2018) that sequenced bacterial 16S rRNA gene to analyze annual bacterioplankton community composition in the euphotic zone (up to $21 \mathrm{~m}$ water depth) of Lake Garda (max. water depth $350 \mathrm{~m}$ ), there are, to the best of our knowledge, no spatiotemporal comparative studies of cyanobacterial succession across different water layers and seasons in deep temperate lakes and in combination with cyanobacteria-specific marker gene analysis.

In this study, we integrate highly resolved sampling throughout the year 2019 with high-throughput amplicon sequencing and quantitative PCR to unravel seasonal succession dynamics of pelagic cyanobacteria community composition (CCC) and abundance as well as possible niche segregation in Lake Tiefer See near Klocksin (TSK). We aim to understand the spatiotemporal succession dynamics of cyanobacteria and their potential lake environmental drivers in deep, temperate hard-water lakes. Lake Tiefer See is ideal for this study because with $62 \mathrm{~m}$ water depth it belongs to the deepest lakes in northeastern Germany. In addition, since the beginning of the last decade, Lake Tiefer See has been the focus of an extensive and high-resolution climate monitoring program as well as several paleolimnological climate reconstruction investigations (e.g., Dräger et al., 2019; Nwosu et al., 2021a; Roeser et al., 2021).

\section{MATERIALS AND METHODS}

\section{Study Site}

The hard-water Lake Tiefer See is located in the natural park "Nossentiner/Schwinzer Heide" in the southern Baltic lowlands (Figure 1A). The lake basin was formed during the last glaciation as part of a subglacial channel system in a morainic terrain and the present lake is part of the Klocksin-Lake-Chain (Dräger et al., 2017). The lake has a maximum depth of $62 \mathrm{~m}$ and no major inflow and outflow with a surface area of about $0.75 \mathrm{~km}^{2}$, and catchment area of about $5.5 \mathrm{~km}^{2}$ dominated by glacial till. The area around Lake Tiefer See is characterized by a warm-temperate climate at the transition from oceanic to continental conditions. Mean monthly air temperatures range from $0^{\circ} \mathrm{C}$ in January to $17-$ $18^{\circ} \mathrm{C}$ in July with maxima up to $30^{\circ} \mathrm{C}$ and minima down to $-5^{\circ} \mathrm{C}$. Mean monthly precipitation varies between $\sim 40 \mathrm{~mm}$ during winter and $\sim 60 \mathrm{~mm}$ in summer with a mean annual precipitation of 560-570 mm (Roeser et al., 2021). Although the catchment is mainly used for agriculture (Theuerkauf et al., 2015), the direct shore-line of the lake is covered by a fringe of trees and there is no anthropogenic infrastructure such as buildings and roads at the lakeshore. The present-day lake status is oligo-mesotrophic and the circulation mode is either mono- or dimictic, depending on the formation of a winter ice cover (Dräger et al., 2017).

\section{Collection of Water Samples}

Water samples were taken monthly between 30th January and 28th November 2019 close to the spot of the lake's maximum depth $(\sim 62 \mathrm{~m}$; Figure 1A), where the floating weather monitoring station is also installed. The sampled water depths were $1,3,5,7,10,15,20,40,45$, and $50 \mathrm{~m}$. A sample volume of $250 \mathrm{~mL}$ lake water was collected for the upper water depths of $1,3,5 \mathrm{~m}$ and pooled $(750 \mathrm{~mL})$, representing the epilimnion. Likewise, volumes of $375 \mathrm{~mL}$ were collected for the lower water depths 45 and $50 \mathrm{~m}$ and pooled $(750 \mathrm{~mL})$, representing the hypolimnion. For each of the other depths 7, 10, 15, 20, and $40 \mathrm{~m}$, respectively, $750 \mathrm{~mL}$ water samples were collected. The 


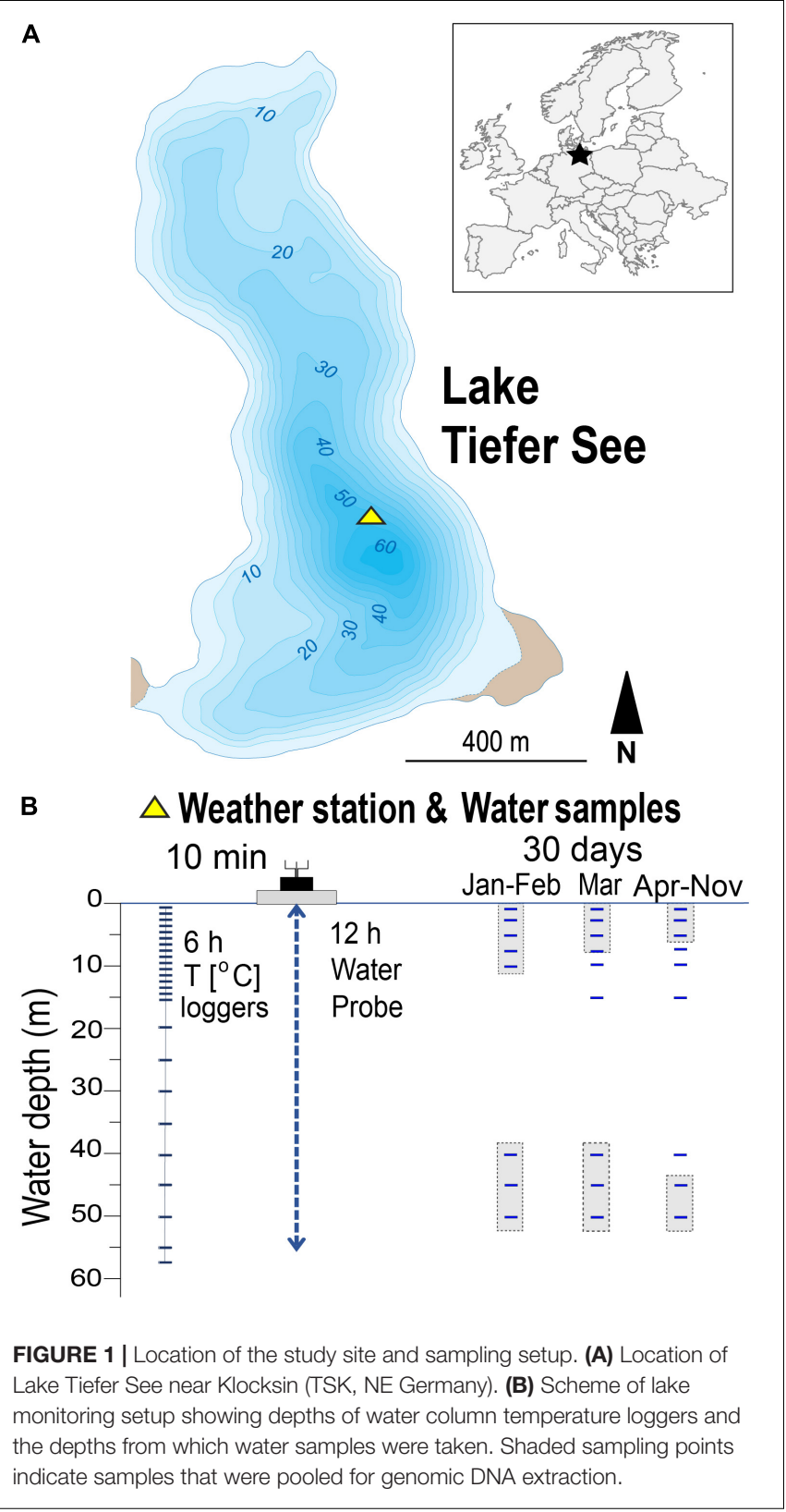

samples were collected in sterile glass bottles (Schott Duran ${ }^{\circledR}$, Germany), which were first flushed with lake water from the respective depths before samples were collected and transported in cold dark boxes to the laboratory where they are stored in refrigerators. They were then, along with blank water (autoclaved deionized water), filtered within $24 \mathrm{~h}$ after fieldwork using $0.2 \mu \mathrm{m}$ cellulose filters (Sartorius AG, Germany) and stored at $-20^{\circ} \mathrm{C}$ until nucleic acid extraction (Kurmayer et al., 2017).

\section{Lake Physicochemical Parameters}

Measurements of the physicochemical parameters $\mathrm{pH}$, dissolved oxygen (DO), turbidity, conductivity, and chlorophyll-a (Chla) in the water column were conducted automatically using a multi-parameter water quality probe (YSI 6600 V2, Yellow
Springs United States) in 0.5-1-m steps and 12-h resolution. The Chla is used here as an indicator of phytoplankton biomass production. Owing to technical problems, data in February were only collected on 2 days (1st and 28th), and in March no data were recorded between the 2 nd and the 10 th. Water temperature was measured using 26 depth-stationary data loggers (HOBO Water Temp Pro v2, Onset United States) in 1-m steps from 0 to $15 \mathrm{~m}$ and 5-m steps from 15 to $55 \mathrm{~m}$ water depth (Figure 1B).

Water samples for molecular analyses, nitrate $\left(\mathrm{NO}_{3}{ }^{-}\right)$and total dissolved phosphorus (TDP) analyses were collected monthly. Nitrate measurements were done at the German Research Centre for Geosciences (GFZ) while TDP was determined at the Leibniz Institute for Baltic Sea Research Warnemünde (IOW). Nitrate was measured by suppressed ion chromatography using a SeQuant SAMS anion IC suppressor (EMD Millipore, Billerica, Massachusetts), a S5200 sample injector, a $3.0 \times 250 \mathrm{~mm}$ LCA 14 column and a S3115 conductivity detector (all Sykam, Fürstenfeldbruck, Germany). The eluent was $5 \mathrm{mM} \mathrm{Na}_{2} \mathrm{CO}_{3}$ with $20 \mathrm{mg} \mathrm{L}^{-1}$ 4-hydroxybenzonitrile and $0.2 \%$ methanol. The flow rate was set to $1 \mathrm{~mL} \min ^{-1}$ and the column oven temperature to $50^{\circ} \mathrm{C}$. Detection and quantification limits were calculated based on signal-to-noise $(\mathrm{S} / \mathrm{N})$ ratios of 3 and 10, respectively. All samples were measured in triplicates and every 10 injections a standard was measured to check for drift. Reproducibility was always better than $5 \%$ and the detection limit ranged between 1 and $4 \mu \mathrm{M}$.

For TDP, the water samples were immediately filtered using $0.45 \mu \mathrm{m}$ syringe filters and acidified with sub-boiled $\mathrm{HNO}_{3}$ to $2 \%$ Vol. The TDP was measured by inductively coupled plasma optical emission spectrometry (ICP-OES; iCAP 7400, Duo, Thermo Fisher Scientific) using external calibration and Sc as internal standard. Precision and trueness were checked with the international reference material SLRS-6 (NRCC) spiked with $20 \mu \mathrm{g} \mathrm{L}^{-1} \mathrm{P}$ and were 9.6 and $5.7 \%$, respectively.

\section{Extraction of DNA}

Nucleic acid extractions were carried out in a clean laboratory where no polymerase chain reaction (PCR) had been performed prior to the extraction, following established methods and precautions to limit contamination (Nwosu et al., 2021b). Because of the mixed water column in January and February, water samples for molecular analyses from the water depths 1 , $3,5,7,10 \mathrm{~m}$ were pooled, and reported as the mean depth (5 $\mathrm{m}$; Figure 1B). The water depths 40, 45, $50 \mathrm{~m}$ were equally pooled, and reported as the mean depth $(45 \mathrm{~m})$. In March, when temperatures began to increase, four depths in the water column were reported as follows: 5 (1,3,5, and $7 \mathrm{~m}$ pooled), 10, 20, and $45 \mathrm{~m}$ (40, 45, and $50 \mathrm{~m}$ pooled). Genomic DNA (gDNA) of water samples, blank water filtrations and blank DNA extraction using autoclaved deionized water were extracted from filters using the DNeasy PowerWater Kit (QIAGEN, United States) following the manufacturer's specifications. The extracted gDNA was eluted in $100 \mu \mathrm{L}$ elution buffer, quantified with the Qubit dsDNA HS Assay Kit (Invitrogn, United States) and stored at $-20^{\circ} \mathrm{C}$ pending downstream analysis. 


\section{Quantification of Cyanobacteria Abundance}

Total cyanobacteria were quantified with a SYBRGreen quantitative PCR (qPCR) assay amplifying specifically the cyanobacteria $16 \mathrm{~S}$ rRNA-ITS (internal transcribed spacer) region ca. 350 bp using the primers CSIF (5'-GYCACGCCC GAAGTCRTTAC-3') and 373R (5'-CTAACCACCTGAGCT AAT-3') (Janse et al., 2003). The final volume of the qPCR reactions was $20 \mu \mathrm{L}$ containing $10 \mu \mathrm{L}$ of KAPA SYBR ${ }^{\circledR}$ FAST qPCR Master Mix (Sigma-Aldrich, Germany), $0.2 \mu \mathrm{L}$ of each forward and reverse primer $(100 \mu \mathrm{M}$, Biomers), $5.8 \mu \mathrm{L}$ PCR water and $4 \mu \mathrm{L}$ of template DNA. The qPCR program consisted of an initial polymerase activation step $\left(95^{\circ} \mathrm{C}\right.$ for $\left.15 \mathrm{~min}\right)$, followed by 40 cycles of denaturation at $94^{\circ} \mathrm{C}$ for $60 \mathrm{~s}$, annealing at $60^{\circ} \mathrm{C}$ for $60 \mathrm{~s}$ and extension at $72^{\circ} \mathrm{C}$ for $60 \mathrm{~s}$. The qPCR program was followed by a melting curve step from 70 to $95^{\circ} \mathrm{C}$ at a transition rate of $1^{\circ} \mathrm{C}$ per $5 \mathrm{~s}$ to determine the specificity of the amplification. The amplified products were confirmed with agarose gel electrophoresis. Tenfold dilution standards were prepared from gDNA of Synechocystis for each qPCR assay, ranging from $4.7 \times 10^{7}$ to $4.7 \times 10^{3}$ copies $\mathrm{ng}^{-1} \mathrm{DNA}$ to create the standard curves from which the quantification cycle $(C q)$ values were determined (Bustin et al., 2009). All qPCR assays were performed in triplicates on a CFX96 real-time thermal cycler (Bio-Rad Laboratories Inc., United States). The copy numbers of the $16 \mathrm{~S}$ rRNA-ITS region were calculated after Savichtcheva et al. (2011). The obtained values were the mean triplicates of each sample expressed as cyanobacterial abundance normalized to extracted DNA (copies $\mathrm{ng}^{-1}$ DNA) with a minimum and maximum quantification efficiency of 91 and $94 \%$, respectively.

\section{Sequence Libraries Preparation}

Cyanobacteria-specific primers CYA359F (5'-CGGACGGGTG AGTAACGCGTG-3') and CYA784R (5'-ACTACWGGGGTA TCTAATCCC-3') (Nübel et al., 1997) that amplify a $>400$ nt-long fragment of the V3 - V4 regions of the 16S rRNA gene were used for preparing two Illumina high-throughput sequencing (HTS) libraries. The primers had unique tags that served to differentiate the samples. The samples and negative controls (that is, a reaction with PCR water as template) were amplified in a $50 \mu \mathrm{L}$ volume PCR reaction, comprising $10 \mathrm{X}$ Pol Buffer C (Roboklon GmbH, Berlin, Germany), $25 \mathrm{mM} \mathrm{MgCl}$, $0.2 \mathrm{mM}$ deoxynucleoside triphosphate (dNTP) mix (Thermo Fisher Scientific), $0.5 \mathrm{mM}$ of each primer (TIB Molbiol, Berlin, Germany), and 1.25 U of Optitaq Polymerase (Roboklon). The volume of the template DNA used in each reaction varied between 1 and $4 \mu \mathrm{L}$ depending on the genomic DNA concentration. The PCR program included a first denaturation step at $95^{\circ} \mathrm{C}$ for $10 \mathrm{~min}$, followed by 35 cycles at $95^{\circ} \mathrm{C}$ for $15 \mathrm{~s}$, annealing at $60^{\circ} \mathrm{C}$ for $30 \mathrm{~s}$, extension at $72^{\circ} \mathrm{C}$ for $45 \mathrm{~s}$ and a final extension step at $72^{\circ} \mathrm{C}$ for $5 \mathrm{~min}$. To avoid cross-contamination, the PCR reactions were done monthly, after each sampling. Furthermore, to control for reproducibility of the PCR and sequencing results, all samples were amplified in a second PCR run (technical replicates). The tagged PCR products were then purified with the Agencourt AMPure XP kit (Beckman Coulter, Switzerland) and eluted in $30 \mu \mathrm{L}$ DNA/RNA-free water. The purified product was quantified with a Qubit 2.0 Fluorometer. Equimolar concentrations of all samples and negative purified PCR controls were pooled into a multiplex library $(n=48$ samples and 2 negative controls). Similarly, equimolar concentrations of all sample technical replicates including negative controls were pooled into a second multiplex library $(n=48$ technical replicates and 2 negative controls). The libraries were paired-end sequenced $(2 \times 300 \mathrm{bp})$ on an Illumina MiSeq system at Eurofins Scientific (Constance, Germany).

\section{Bioinformatics}

The obtained 10,546,152 sequence reads were quality checked on a raw fastq file with FastQC (Andrews et al., 2015). The reads were demultiplexed, first by using the "make.contigs" function in Mothur (v.1.39.5: pdiff $=2$, bdiff $=1$, and default setting for others) (Schloss et al., 2009). Based on the report files generated by "make.contigs" function, the sequence identifiers were retrieved for those sequences with minimum overlap (length $>25$ ), maximum mismatches $(<5)$, and the maximum number of ambiguous bases of zero (which means there is no base marked with "N"). According to the sequence identifiers from the previous step the sequences were extracted with "filterbyname.sh" function from BBtools (Bushnell et al., 2017) from the raw paired-end fastq file. This step was followed by correcting the sequence orientation and removing sample unique barcodes by using extract_barcodes.py in QIIME1 (Caporaso et al., 2010) and finally, the primers were removed using awk script (Aho et al., 1979). The demultiplexed sequences were fed to DADA2 (Callahan et al., 2016) for filtering, dereplication, chimera check, sequence merge, and ASV (amplicon sequence variants) calling. The output of DADA2 was further fed to QIIME2 (Bolyen et al., 2019) for taxonomic assignment against the SILVA138 database (Quast et al., 2013).

\section{Data Availability}

Sequencing data and metadata are deposited at the European Nucleotide Archive (ENA) under Bio Project accession number PRJEB40406 as well as sample accession numbers ERS5083566ERS5083644.

\section{Sequence Data Processing and Statistics}

The two libraries were merged together by taking the average of their relative abundances. Bubble plots were used to illustrate differences in seasonal and spatial cyanobacteria assemblage and produced with the free software tool ${ }^{1}$. Alpha and beta diversity estimations, Spearman correlation and multivariate permutational analysis of variance (PerMANOVA) were performed using the PAST v4.01 software (Hammer et al., 2001). Two-way analysis of variance (ANOVA) tests, nonmetric multidimensional scaling (NMDS) and distance-based redundancy analysis (dbRDA) were performed using the "vegan" package in R (Oksanen et al., 2019). Prior to alpha diversity calculation (richness, Shannon diversity and Pielou's evenness)

\footnotetext{
${ }^{1}$ http://shiny.raccoome.de/bubblePlot/
} 
the ASV read counts were rarefied to account for differences in sequencing depth (2,200 read counts per sample) using the "rtk" package in R (Saary et al., 2017). Also, before beta diversity measurements, the ASV cut-off was set to $0.1 \%$ to eliminate very rare taxa. The statistical significance level for uni- and multivariate statistical analyses was set to $<0.05$. To determine which lake factors have a significant impact on cyanobacteria spatiotemporal alpha diversity dynamics a two-way ANOVA (additive and interactive models) test was used to evaluate the effect of seasons and stratification zones (epi-, meta- and hypolimnion) on cyanobacteria species richness and evenness. In the ANOVA models, species richness or evenness was the response variable while season and stratification zones were the predictors. The seasons were defined based on changes in the water column as reveled by multi-parameter probe data. The ANOVA models' assumptions were evaluated with Tukey'shonestly-significant-difference (TukeyHSD) post hoc tests. An NMDS ordination based on the Bray-Curtis dissimilarity matrix was used to determine whether the samples at the ASV level showed distinct grouping patterns. To assess whether the grouping patterns of cyanobacterial communities at the ASV level as revealed by the NMDS were significantly different from each other a non-parametric PerMANOVA test based on Bray-Curtis matrix using seasons as predictors was conducted. Hellinger-transformed cyanobacteria absolute read counts data were used in the NMDS analysis and PerMANOVA test (Legendre and Gallagher, 2001). To align pooled water samples with depth-specific environmental variables, the averages of the environmental variables from the corresponding water depths were calculated. For example, for the reported mean water depth $5 \mathrm{~m}$ (water depths $1,3,5,7$, and $10 \mathrm{~m}$ ) in January, average water temperature from the depths $1,3,5,7,10 \mathrm{~m}$ on the day of sample collection was aligned to the reported mean sample depth $5 \mathrm{~m}$. To assess the correlation of Cyanobium ASVs 0005, 0008, and 0014 abundance to environmental parameters a Spearman's rank correlation coefficient was calculated. Prior to the correlation analysis the environmental data (predictors) were standardized by subtracting the mean and dividing by the standard deviation (Z-Score) and the Cyanobium ASVs 0005, 0008, and 0014 (response variables) read counts were Hellinger transformed. Standardized environmental data were also fitted into the dbRDA model. In this model, environmental and cyanobacteria community data were the explanatory and response variables, respectively. The dbRDA analysis was performed using the "capscale" function and Bray-Curtis distance in "vegan". The model and axes significance were tested by a Monte Carlo permutation test $(n=999)$ using the "anova.cca" function in "vegan". Collinearity in the explanatory variables was tested with a variance inflation factor (VIF) using the "vif.cca" function in "vegan". Explanatory variables were then additively tested until only those with a VIF score $<10$ remained. The significant subset of explanatory variables that may explain the variability of cyanobacterial community composition was determined via forward selection using the function "ordiR2step" function in "vegan". Variation partitioning analysis (VPA) (Legendre et al., 2005) with redundancy analysis (RDA) was implemented on two categories of explanatory variables, that is, physicochemical parameters (temperature, $\mathrm{pH}$, turbidity, conductivity, and $\mathrm{DO}$ ) and nutrients (TDP and $\mathrm{NO}_{3}{ }^{-}$) to identify their unique and interactive effects on the cyanobacteria population dynamics (response variable). The significance of the fractions of variability explained by the categories was tested and determined via a Monte Carlo permutation test $(n=999)$ in CANOCO5 (Smilauer and Leps, 2014).

\section{RESULTS}

\section{Water Column Physicochemical Parameters}

Temperature and dissolved oxygen (DO) in the water column of Lake Tiefer See (Figures 2A,B) showed that in 2019 thermal stratification began in early April and continued beyond late November. Highest epilimnion temperatures $\left(>22^{\circ} \mathrm{C}\right)$ were recorded during summer months. In the epilimnion (0-6 m) three periods with high temperatures followed by cooling of $\sim 5^{\circ} \mathrm{C}$ drop occurred. The first lasted the entire month of June $\left(T_{\max }=21.6^{\circ} \mathrm{C}, T_{\text {average }}=20^{\circ} \mathrm{C}\right)$ while the second phase covered the last week of July until the first week of August $\left(T_{\max }=20.9^{\circ} \mathrm{C}, T_{\text {average }}=19^{\circ} \mathrm{C}\right)$. The last warm period was recorded from late August to the first few days in September $\left(T_{\text {max }}=20.7^{\circ} \mathrm{C}, T_{\text {average }}=17^{\circ} \mathrm{C}\right)$. Oxygen depletion in the bottom water started circa 3 weeks after the onset of thermal stratification and the onset of pelagic productivity. The DO reached minimum values $\left(\sim 0.67 \mathrm{mg} \mathrm{L}^{-1}\right)$ at $40-50 \mathrm{~m}$ water depth between October and November (Figure 2B). Additionally, Lake Tiefer See developed a zone of metalimnetic oxygen minimum between 10 and $13 \mathrm{~m}$ from June to September. Enhanced $\mathrm{pH}$ and Chla values (Figures 2C,D) reflect the first algal-blooms in mid-April between 1 and $7 \mathrm{~m}$ water depth, shortly before the onset of lake stratification. From late March until mid-July, peak Chla were observed at approximately $7 \mathrm{~m}$ water depth, and at $10 \mathrm{~m}$ water depth from August to September (Figure 2D). In winter to early spring, conductivity in the mixed water column ranged between 530 and $540 \mu \mathrm{S} \mathrm{cm}^{-1}$ (Figure 2E). During lake stratification, conductivity was lowest in the epilimnion $\left(<480 \mu \mathrm{S} \mathrm{cm}^{-1} ; 1-7\right.$ $\mathrm{m})$ and highest in the meta- and hypolimnion $\left(>540 \mu \mathrm{S} \mathrm{cm}^{-1}\right.$; 10-60 m). Nitrate concentrations varied between 1 and $2 \mu \mathrm{g}$ $\mathrm{L}^{-1}$, except in October and November where they reached only $0.2 \mu \mathrm{g} \mathrm{L}^{-1}$ (Figure 2F). Turbidity peaked between 5 and 6 NTUs in summer in the upper water column (down to $10 \mathrm{~m}$ ) likely as a combined result of primary productivity and calcite precipitation (Figure 2G). TDP values were generally higher in the hypolimnion, gradually increasing from July through November reaching up to $\sim 70 \mu \mathrm{g} \mathrm{L}^{-1}$ in the bottom waters (Figure 2H). In contrast, the TDP in the epilimnion ranged between 10 and $15 \mu \mathrm{g} \mathrm{L}^{-1}$, except for January and February, when the lake was in an isothermal state and the TDP values were between 20 and $25 \mu \mathrm{g} \mathrm{L}^{-1}$ throughout the mixed water column.

\section{Cyanobacterial Community Composition}

Sequencing of the water samples resulted in a total of $4,864,912$ denoised and error-corrected absolute read counts which DADA2 inferred into 1599 ASVs. The two negative 

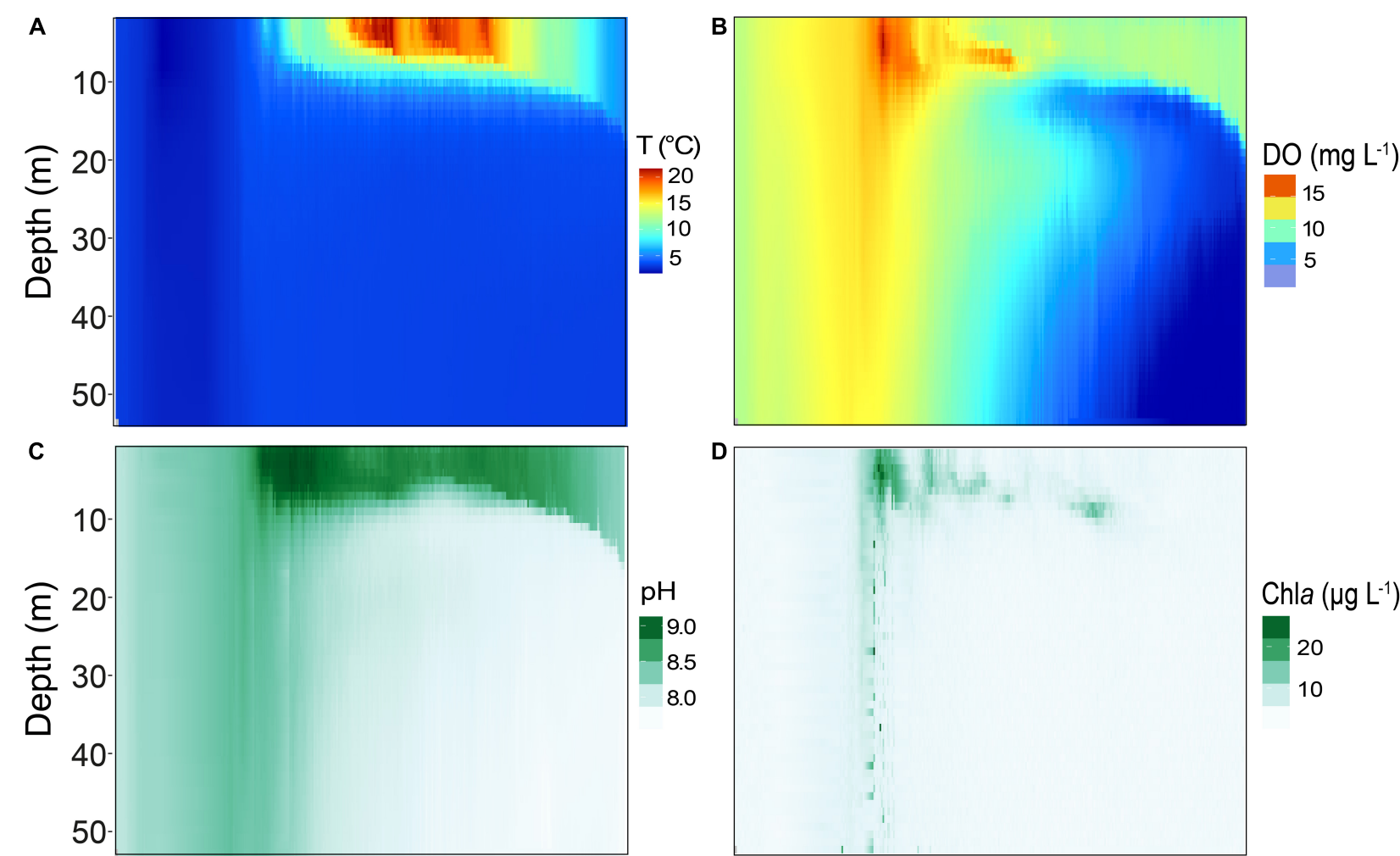

E
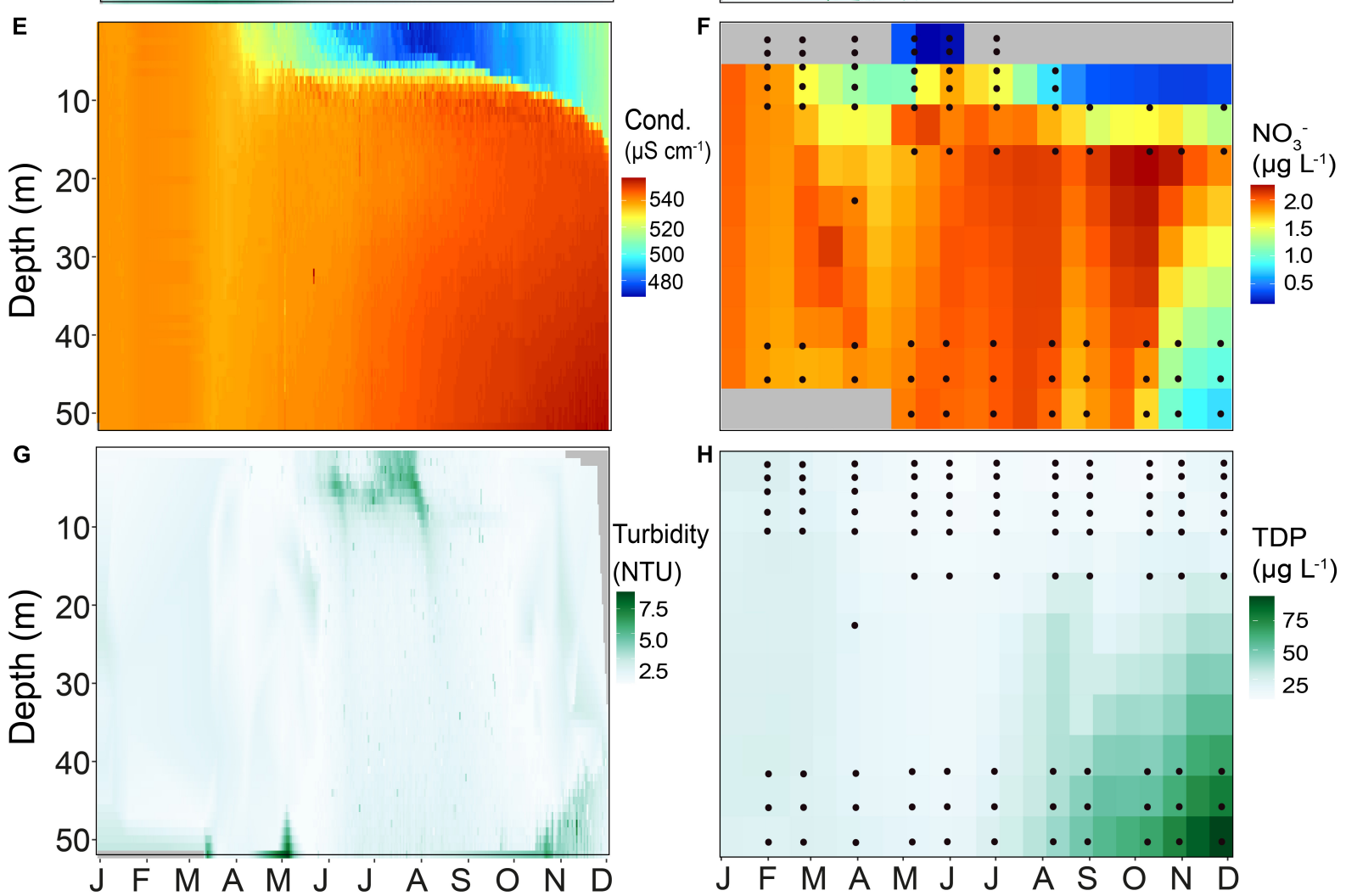

FIGURE 2 | Heatmaps of different physicochemical parameters of Lake Tiefer See for the year 2019 measured in the water column using a multi-parameter probe (YSI 6600 V2), showing (A) Temperature (T), (B) Dissolved oxygen (DO), (C) pH, (D) Chlorophyll a (Chla), (E) Conductivity (Cond.), (F) Nitrate (NO ${ }^{-}{ }^{-}$), (G) Turbidity, and $\mathbf{( H )}$ Total dissolved phosphorus (TDP). Probe data were interpolated for 1 day and $1 \mathrm{~m}$ water depth. Black circles in $\mathrm{NO}_{3}{ }^{-}$and $\mathrm{TDP}$ heatmaps represent the depths from which measurements were taken. The latter were interpolated to 15 days and 5 meters water depth. Gray fields in $\mathrm{NO}_{3}{ }^{-}$heatmap are depths with no data. 
extraction controls that were included in the sequencing run each comprised less than $1 \%$ of the reads (17 ASVs) compared with the sample average and were removed. After ASVs assigned to chloroplasts, non-photosynthetic cyanobacteria (the orders Sericytochromatia and Vampirivibrionia) and other bacteria had been removed, 894 ASVs with a total 2,915,251 read counts remained. Next, global singletons and doubletons (492 ASVs) as well as 201 ASVs that occurred in fewer than three samples over the whole dataset were removed to reduce influence from very rare taxa. The filtered dataset comprised 201 ASVs assigned to photosynthetic cyanobacteria with a combined 2,901,116 absolute read counts and distributed across 96 samples (Supplementary Table 1). Of the 201 ASVs, two were assigned to order level (Cyanobacteriales), six were assigned to family level (2x Leptolyngbyaceae, 2x Coleofasciculaceae, Microcystaceae, Cyanobiaceae), and 193 were assigned to genus level. The ASVs of the genera Planktothrix, Cyanobium, Synechococcus, Snowella, Aphanizomenon, Microcystis, Pseudanabaena, and Gloeocapsa were most abundant. Of the cyanobacterial ASVs with $0.1 \%$ relative abundance, $65 \%$ were assigned to the genus Cyanobium (Figure 3 and Supplementary Figure 1).

\section{Cyanobacterial Seasonal Variation}

A general trend in cyanobacterial 16S rRNA-ITS gene copy numbers was observed with highest mean cyanobacteria abundances in summer $\left(1.2 \times 10^{6}\right.$ copies $\mathrm{ng}^{-1}$ DNA, $\left.n=18\right)$ and fall $\left(6.7 \times 10^{5}\right.$ copies $\left.\mathrm{ng}^{-1} \mathrm{DNA}, n=18\right)$ throughout the water column. In contrast, lower mean cyanobacteria abundances were observed in spring $\left(3.2 \times 10^{5}\right.$ copies $\left.\mathrm{ng}^{-1} \mathrm{DNA}, n=16\right)$ and winter $\left(9.4 \times 10^{4}\right.$ copies $\left.\mathrm{ng}^{-1} \mathrm{DNA}, n=4\right)$, respectively,

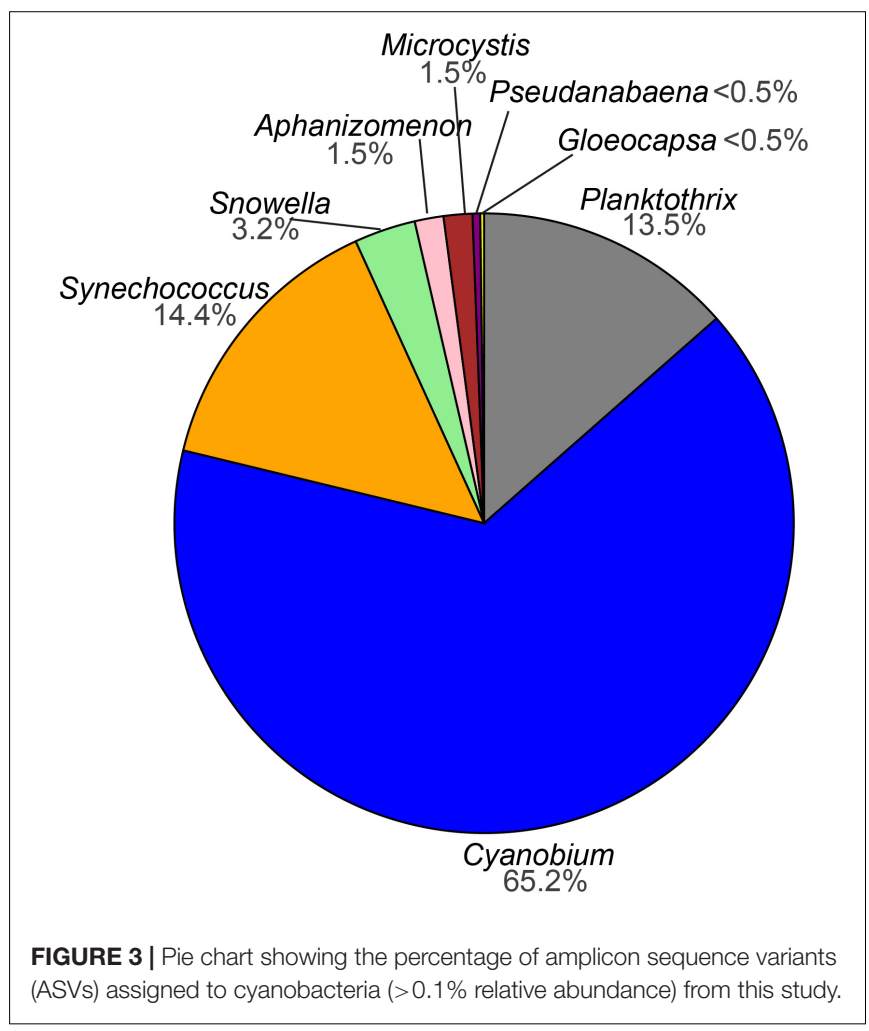

throughout the water column. The highest average numbers of cyanobacterial 16S rRNA-ITS gene copies were measured in the epi- and metalimnion in summer $\left(2.2 \times 10^{6}\right.$ copies $\mathrm{ng}^{-1}$ DNA, $1-10 \mathrm{~m}, n=9)$ and fall $\left(1.1 \times 10^{6}\right.$ copies $\mathrm{ng}^{-1}$ DNA, 1-10 $\mathrm{m}, n=9$ ), while the hypolimnion had the lowest numbers throughout the different seasons, except for winter (Figure 4A).

The spatiotemporal variation was mainly driven by the ASVs belonging to the cyanobacterial orders Synechococcales (Cyanobium, Snowella, and Synechococcus), Nostocales (Aphanizomenon), Chroococcales (Microcystis), and Oscillatoriales (Planktothrix) (Figure 4B). The seasonal and spatial dynamics of the ASVs assigned to the most dominant taxa ( $>1 \%$ relative abundance) in Lake Tiefer See during the study period were as follows. In Winter (January - February), ASV0008 (Cyanobium), and ASV0007 (Synechococcus) were the most abundant $(\geq 30 \%)$ cyanobacteria species throughout the water column. In Spring (March-May), Cyanobium ASV0008 bloomed in the epi- and metalimnion exceeding a relative abundance of $40 \%$. At the same time, in the metalimnion the abundance of Planktothrix ASV0006 increased more than fivefold to $\geq 30 \%$ and was maintained high until late autumn. In the hypolimnion, ASV0004 (Aphanizomenon), and ASV0009 (Microcystis) increased only slightly ( $\geq 5 \%$ ) in spring. In summer, Aphanizomenon ASV0004 (June) and the two Snowella ASVs 0016 and 0022 (August) behaved similarly with increase in abundance from $\sim 2$ to $11 \%$ in the epilimnion. Synechococcus ASV0007 abundance increased to more than $30 \%$ throughout the water column in June. Starting in August, ASVs 0006 and 0014 assigned to Planktothrix and Cyanobium, respectively, subsequently became the most dominant ASVs $(\geq 40 \%)$ in the meta- and hypolimnion, respectively. In fall (October), Cyanobium ASV0005 was the most abundant $(\geq 40 \%)$ in the epi- and hypolimnion. In the metalimnion $(10 \mathrm{~m})$, Planktothrix ASV0006 abundance was higher $(\geq 40 \%)$ than that of Cyanobium ASV005 ( 30\%). Also, the Microcystis abundance increased throughout the water column from 2 to $6 \%$ whereas the Snowella ASVs 0016 and 0022 increased by more than $20 \%$ in the hypolimnion only.

The CCC at the ASV level showed distinct spatial and temporal clustering patterns as shown by NMDS (Supplementary Figure 2), and confirmed by a one-way PerMANOVA test to be significantly different from each other $(p<0.05 ; F=10.72$; Supplementary Table 2).

\section{Cyanobacterial Alpha Diversity Indices}

A two-way ANOVA was used to determine if possible differences in cyanobacteria species richness were driven by seasonality, lake stratification (epi-, meta-, and hypolimnion) and/or an interaction effect of both factors. Species richness was found to be significantly impacted by season $[F(3)=8.046, p<0.05$; Figure 4], but not by depth nor an interaction between both terms. A Tukey post hoc test revealed significant pairwise differences in cyanobacteria species richness between spring and summer (+5.8 species richness; Supplementary Table 3), spring and autumn ( -8.6 species richness), and between epiand hypolimnion depths ( -3.7 species richness). Cyanobacteria 


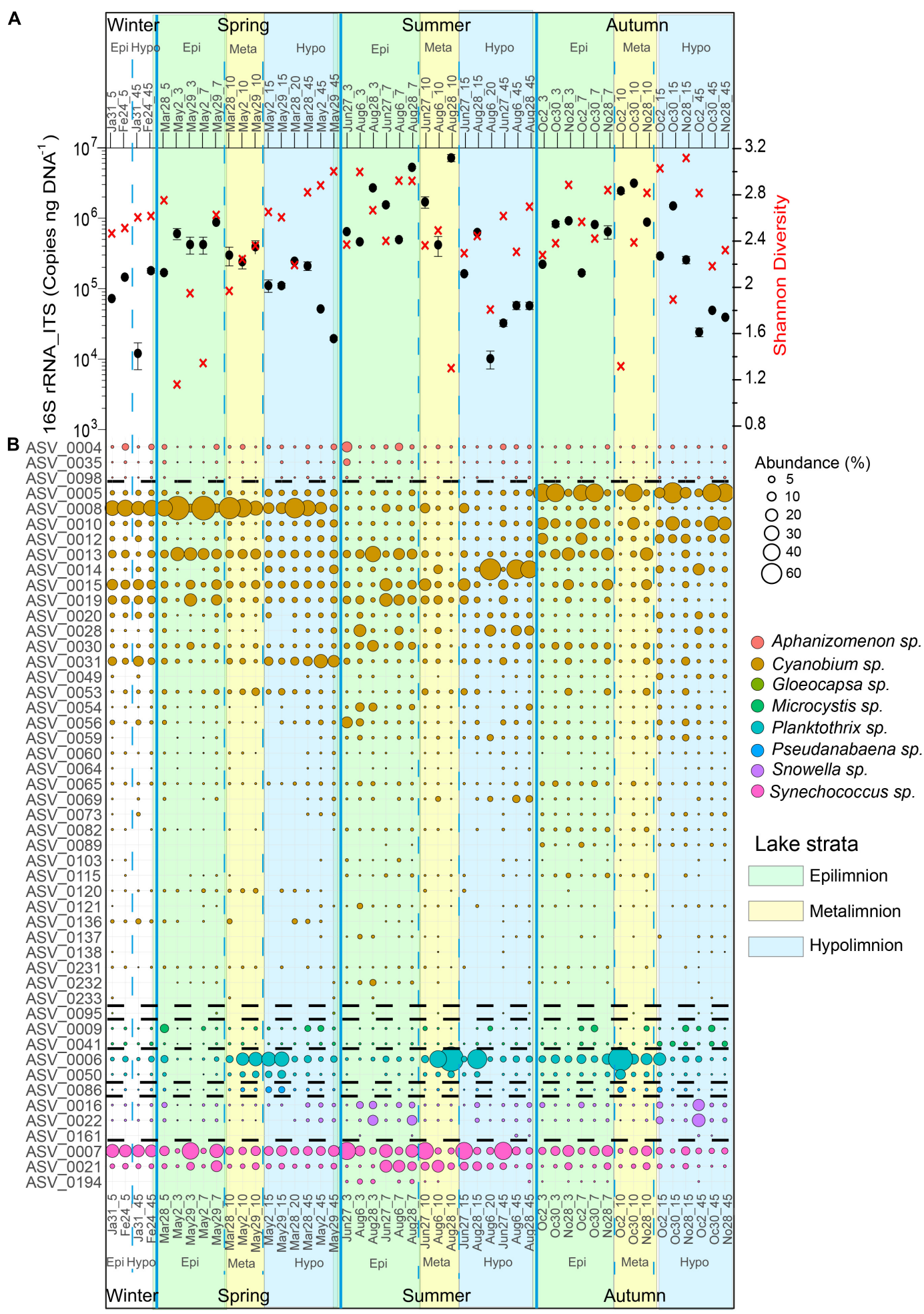

FIGURE 4 | Cyanobacteria community structure, abundance and diversity in Lake Tiefer See throughout the year 2019. (A) Cyanobacterial abundance quantified via GPCR (black dots; Error bars, which are hidden by the dots in some cases, give the standard deviations for three independent amplifications.) and Shannon diversity (red crosses). (B) Bubble plot showing the spatiotemporal variation of cyanobacteria community composition at the amplicon sequence variant level (cutoff $>0.1 \%$ relative abundance). Numbers beside months refer to sampling date while number after the underscore refers to water depth, e.g., May2_10 refers to a sample collected at $10 \mathrm{~m}$ water depth on 2nd May. Epi = epilimnion, Meta = metalimnion, Hypo = hypolimnion. Taxa follow the same order as in the legend and broken lines indicates where the bubbles of one taxon end and the next begins. 
species evenness was not significantly impacted by the seasonal and lake stratification factors (Supplementary Figure 3).

In general, mean cyanobacterial species diversity across the seasons as revealed by Shannon index was lowest in the metalimnion compared to the epi- and hypolimnion (Figures 5, 4A). In the epilimnion, diversity was highest in summer (2.7) and lowest in spring (2.0). Conversely, diversity decreased slightly from spring to summer from 2.2 to 2 in the metalimnion and 2.7 to 2.3 in the hypolimnion. Cyanobacteria diversity in the metalimnion from March to November was between 2.1 and 2.2 .

\section{Relationship Between Certain Cyanobium Amplicon Sequence Variants and Environmental Variables}

We observed a potential niche separation among the three most abundant ASVs 0005, 0008, and 0014 assigned to Cyanobium
(Figures 4B, 6A). Because of the different seasonal relative abundances among the Cyanobium ASVs 0005, 0008, and 0014, we used a rank-based Spearman's correlation coefficient to check potential correlations of these ASVs with environmental parameters (Figures 6A,B). The ASV0005 which was dominant in fall had a significant positive correlation with TDP $\left(R_{S}=0.52\right)$, and negatively correlated to temperature, $\mathrm{pH}$, turbidity and $\mathrm{DO}$ although insignificant $\left(R_{S}>-0.4\right)$. ASV0008 which was most abundant in winter and spring correlated positively with $\mathrm{pH}$ $\left(R_{S}=0.48\right)$ and DO $\left(R_{S}=0.76\right)$. Lastly, the ASV0014 which dominated the hypolimnion in summer correlated positively with TDP and conductivity $\left(R_{S}>0.52\right)$ and negatively with temperature and $\mathrm{pH}\left(R_{S}>-0.47\right)$.

A dbRDA was used to ascertain the environmental parameters responsible for the variation in the general cyanobacterial seasonal communities (Figure 7). The dbRDA model explained $48 \%$ of the total observed community variation and identified temperature, turbidity, $\mathrm{TDP}, \mathrm{NO}_{3}{ }^{-}, \mathrm{pH}$, conductivity and $\mathrm{DO}$ as

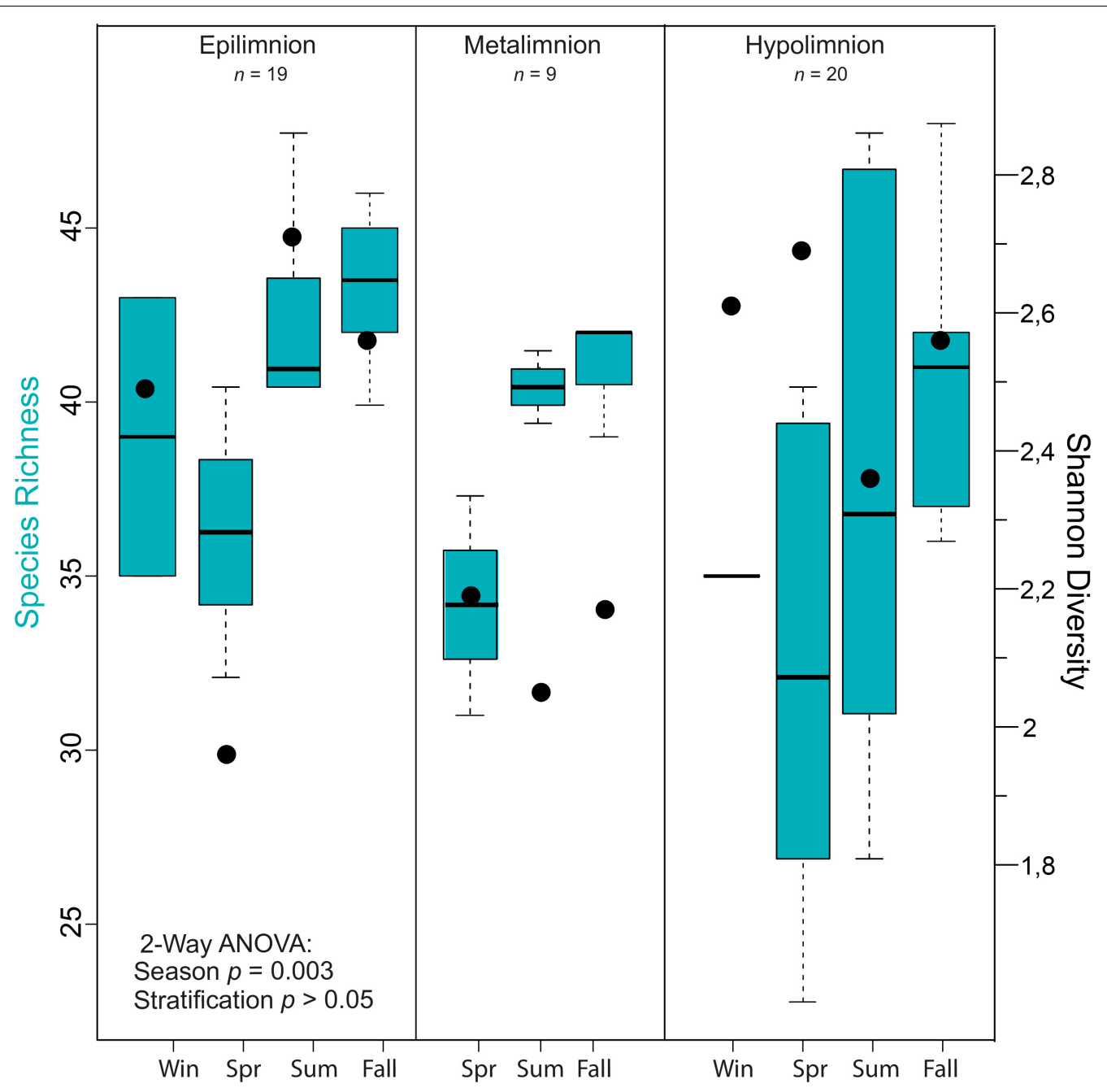

FIGURE 5 | Alpha diversity of cyanobacteria communities in Lake Tiefer See. Box plots showing the results of seasonal and stratification effects on cyanobacteria richness in Lake Tiefer See via a two-way analysis of variance (ANOVA) analysis and Shannon diversity indices shown by black dots. The ANOVA models' assumptions were evaluated with Tukey's honestly-significant-difference (TukeyHSD) post hoc tests. 

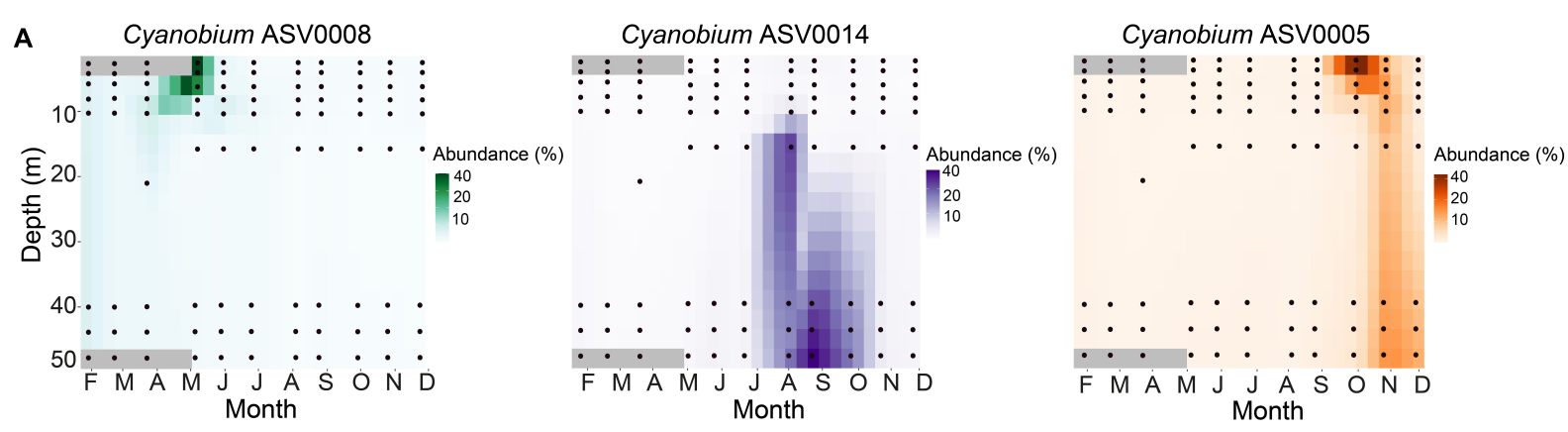

B

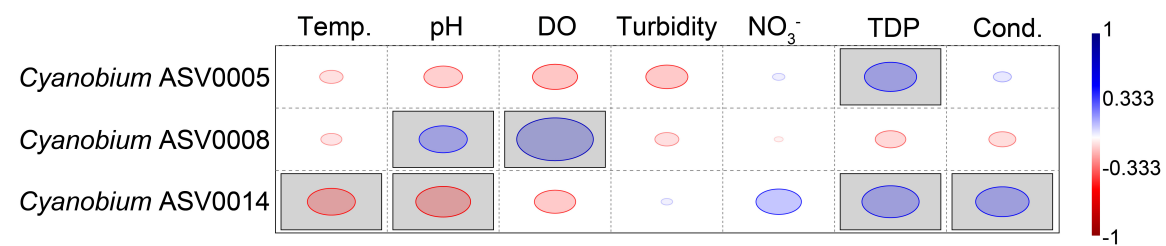

FIGURE 6 | Dynamics of the three most abundant Cyanobium ASVs and correlation with environmental parameters. (A) Heatmaps show the spatiotemporal distribution across the water column of Lake Tiefer See. Data were interpolated for 10 days and $3 \mathrm{~m}$ water depth. Black circles represent the depths of water sample collection. (B) Rank-based Spearman correlation of the most abundant Cyanobium ASVs with lake physicochemical parameters in Lake Tiefer See. Gray-shaded squares are significant at $p<0.05$ with Bonferroni $p$-value correction. Blue circles show positive while red circles show negative correlation. Temp. $=$ Temperature, $\mathrm{DO}=$ dissolved oxygen, $\mathrm{NO}_{3}{ }^{-}=$nitrate, TDP = total dissolved phosphorus, Cond. = conductivity.

environmental variables that significantly shaped cyanobacterial communities in Lake Tiefer See over the investigated seasons (Table 1). Furthermore, canonical VPA (Figure 8) was used to determine the percentage of variation explained by nutrients, physicochemical parameters as well as their combined effect on cyanobacterial population. The physicochemical parameters (23\%; temperature, DO, turbidity, conductivity, and $\mathrm{pH}$ ) and nutrients $\left(11.2 \%\right.$; $\mathrm{TDP}$ and $\left.\mathrm{NO}_{3}{ }^{-}\right)$were the groups of factors that significantly explained most of the variability in cyanobacteria composition in Lake Tiefer See. The interaction between both groups accounted for $6.1 \%$ of community variation, while $60 \%$ of the variation remained unexplained. Turbidity was not included in the VPA model because it has been shown to be triggered by both abiotic sediment resuspension in the bottom waters and biotic biomass production in the upper waters. However, when turbidity is included as part of the physicochemical parameters, total amount of variation explained by the VPA model increases to $45 \%$ (accounting for an additional $5 \%$ ).

\section{DISCUSSION}

Altogether the cyanobacteria community in Lake Tiefer See is dominated by the orders Synechococcales and Oscillatoriales indicative of its oligo-mesotrophic status (Callieri et al., 2012a; Soule and Garcia-Pichel, 2019). This aligns with observations in several natural and artificial lakes e.g., periAlpine lakes (Monchamp et al., 2018), sub-Alpine deep and shallow lakes as well as reservoirs and fish ponds (Vörös et al., 1998). However, our study shows a previously unknown cyanobacteria inter-species spatio-temporal variation in a temperate hard-water lake. Although this study spanned a monomictic lake circulation mode, its results can be extrapolated to years with similar circulation modes provided other lake environmental parameters remain the same. This is based on the premise that despite the potential annual variability in interspecies relative abundances which are mainly influenced by fluctuations in lake environmental parameters, a general pattern would still be observed. That is, cyanobacteria seasonal variation would typically begin with an increase in abundance of nitrogenfixing taxa which utilize sediment resuspended nutrients made available during water turnover in spring (e.g., Aphanizomenon), then a breakdown in their population in summer e.g., by fungal parasitism (Gerphagnon et al., 2015), and followed by an increase in abundance of non-nitrogen fixers e.g., Planktothrix sp. at the base of the euphotic zone or in the epilimnion (Walsby and Schanz, 2002).

\section{Succession and Seasonal Variation of Cyanobacterial Communities}

The observed seasonal variation of the CCC suggests the formation of distinct subpopulations in Lake Tiefer See dominated by a few taxa belonging to Synechococcales (Cyanobium, Snowella, and Synechococcus), Nostocales (Aphanizomenon- spring to summer), Chroococcales (Microcystis- fall), and Oscillatoriales (Planktothrix- late spring to fall). The interplay of abiotic factors and nutrients such as temperature, turbidity, $\mathrm{DO}, \mathrm{pH}$, conductivity, $\mathrm{NO}_{3}{ }^{-}$, and TDP were likely responsible for shifting the CCC and the abundance of the dominant taxa (Figures 7, 8 and Table 1). This observation adds to previous amplicon-based CCC studies in shallow and deep temperate lakes (Diao et al., 2017; 


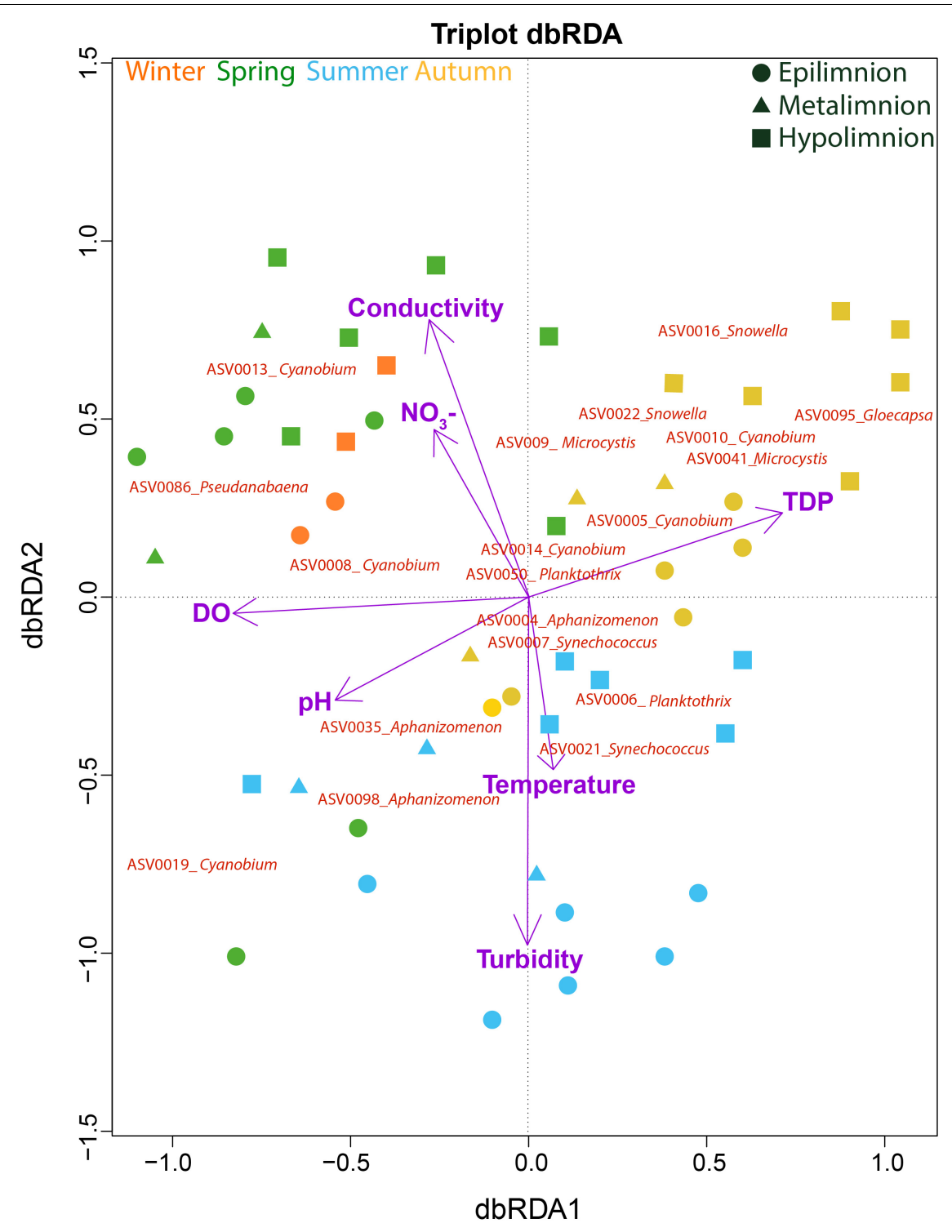

FIGURE 7 | Cyanobacterial composition in relation to environmental variables. Distance-based Redundancy Analysis (dbRDA) on the effect of environmental variables on cyanobacteria community composition. The total variation explained by the dbRDA model was $48 \%$. The samples are color-coded according to seasons. The environmental variables explaining the variation in cyanobacteria community were all significant (adjusted $R^{2}=0.34$ ) and are projected as purple vectors. The response variables are shown at the ASV level.

Salmaso et al., 2018). Unlike in the nearby Lake Stechlin, where Dolichospermum circinale and Aphanizomenon flosaquae were the dominant cyanobacteria taxa (Dadheech et al., 2014), Cyanobium, Synechococcus, and Planktothrix were most abundant in Lake Tiefer See (Figures 3, 4B). The dominance of these taxa in Lake Tiefer See may be attributed to physiological advantages like rapid growth (Cyanobium, Synechococcus), colony formation (Cyanobium), and cell buoyancy regulation (Planktothrix, Nwosu et al., 2021b). Consequently, these taxa are able to better adapt to the seasonally changing in-lake conditions (Reynolds et al., 1987; Callieri and Stockner, 2000; Carey et al., 2012). Our observation of higher abundance of potential toxin-producing taxa (Planktothrix, Aphanizomenon, and Microcystis) accompanied by a lower picocyanobacterial abundance (Cyanobium and Synechococcus) is in line with that from other temperate lakes with varying depths and trophic status (Callieri et al., 2012b). Planktothrix, Aphanizomenon, and Microcystis were shown to cause surface blooms either directly because of anthropogenic nutrient loading e.g., via agriculture (Paerl and Huisman, 2008; Sukenik et al., 2015) or indirectly by continuous warming (Wagner and Adrian, 2009; Winder et al., 2009).

The seasonality of cyanobacteria observed in Lake Tiefer See is similar to known succession patterns in various temperate lakes which typically begins in spring when picocyanobacteria and nitrogen-fixing taxa (e.g., Aphanizomenon that survived the 
A Residual variation $60 \%$

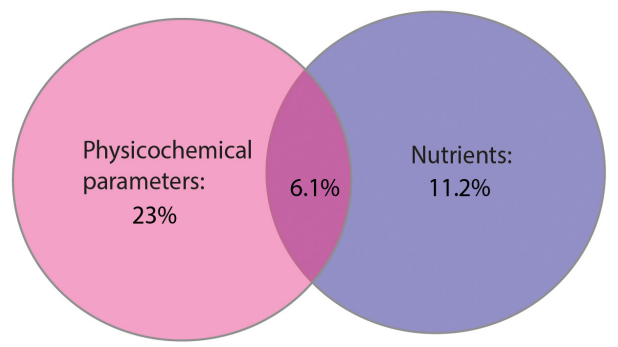

B Residual variation $56 \%$

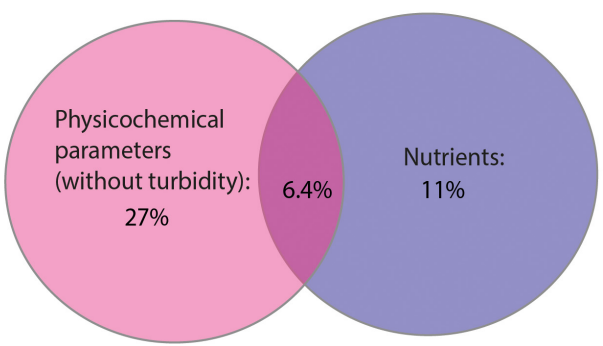

FIGURE 8 | Venn diagrams displaying the results of the variation partitioning analysis (VPA). The two explanatory matrices used contained variables on lake internal physicochemical parameters (A) (temperature, dissolved oxygen, turbidity, conductivity and pH) and nutrients (total dissolved phosphorus and nitrate). (B) (temperature, dissolved oxygen, conductivity and $\mathrm{pH}$ ) and nutrients (total dissolved phosphorus and nitrate). Each circle represents the portion of variation accounted for by each explanatory matrix or a combination of them. The significance of the fractions of variability explained by the categories was determined via a Monte Carlo permutation test $(n=999)$.

winter in sediments) become dominant by taking advantage of increasing temperature, light intensity, and the nutrients made available during spring mixing of the lake (Walsby, 2005; Hense and Beckmann, 2006; Kaiblinger et al., 2007). This leads to a cyanobacterial bloom evidenced by an increase in the total cyanobacteria abundance in the upper waters (epi- and metalimnion) in early spring likely associated with increase in bio-productivity, oxygen concentrations and the higher $\mathrm{pH}$ of the epilimnion (Figures 2B,D, 4B; Roeser et al., 2021). The onset of stratification in Lake Tiefer See as seen from the temperature, DO and other parameters in the upper water column (i.e., mid-April, Figure 2B), follows an increase in bio-productivity from the aforementioned cyanobacteria groups that grow optimally as temperature begins to increase. The breakdown of fall cyanobacteria populations (e.g., picocyanobacteria and Aphanizomenon) is likely due to factors such as viral lysis (Personnic et al., 2009), increased epilimnion turbidity resulting from biomass production in spring, subsequent lower light intensity, nutrient depletion, predation and grazing by zooplankton communities like rhizopods, ciliates, rotifers (Gerphagnon et al., 2015), Daphnia (Urrutia-Cordero et al., 2016), copepods (Ger et al., 2016),

TABLE 1 | Summary of significant explanatory parameters used in the distance-based redundancy analysis (dbRDA) model.

\begin{tabular}{lccc}
\hline Explanatory variable & AIC & Pseudo- & $\boldsymbol{p}$ \\
\hline DO & 159.73 & 8.77 & 0.001 \\
Conductivity & 156.75 & 4.92 & 0.002 \\
Turbidity & 157.26 & 4.92 & 0.002 \\
$\mathrm{TDP}$ & 154.76 & 4.56 & 0.002 \\
$\mathrm{pH}$ & 153.98 & 4.42 & 0.005 \\
$\mathrm{NO}_{3}{ }^{-}$ & 152.98 & 3.56 & 0.004 \\
Temperature & 150.95 & 3.07 & 0.008 \\
\hline
\end{tabular}

The model explained $48 \%$ of the total variation $(p=0.001)$. The significance of the environmental variables was tested by 999 Monte Carlo permutations and were selected by forward selection (Adjusted $R^{2}=0.34$ ).

AIC, Akaike information criterion. and/or parasitic fungi (Jia et al., 2010). In fall, the concurrent resuspension of shallow-water sediments together with the release of phosphorus into the water column favored a second cyanobacteria bloom (Figure 2H). Our data show that this bloom comprises mainly cyanobacterial ASVs assigned to Microcystis, Snowella, Planktothrix, and Cyanobium.

The peak in total cyanobacteria abundance in late August in the metalimnion ( $10 \mathrm{~m}$; Figure $4 \mathrm{~A}$ ) may have resulted from the presence of a density gradient zone during lake stratification that prevent complete downward transport of the CCC from the water column to the sediments, especially of buoyant and filamentous taxa like Planktothrix (Halstvedt et al., 2007; Boehrer and Schultze, 2008). Also, the peak in summer cyanobacteria abundance in upper waters aligns with previous findings which identified temperature as an important factor leading to increase of cyanobacteria populations in lakes in central and northern European regions (Richardson et al., 2018). Considering that the copy numbers of the $16 \mathrm{~S}$ rRNA gene among cyanobacteria genera have a low range in variability $(2.7 \pm 1.0$ copies; Vètrovský and Baldrian, 2013), we do not think the abundance and sequencing data from our study are skewed.

We further observed that seasonal changes significantly altered species richness especially in the epi- and metalimnion in Lake Tiefer See (Figure 4). The increase in water temperature, light and nutrient availability likely explains the significant increase in species richness between spring and summer in the epi- and the metalimnion. In addition, the Shannon species diversity minima in spring (epilimnion) and summer (meta- and hypolimnion) are attributed to the dominance of a few ASVs assigned to Cyanobium and Planktothrix and supported by the uneven species distribution during these seasons (Supplementary Figure 3). An environmental factor that likely affects the CCC in Lake Tiefer See is the lake circulation mode which depends on the formation of a winter ice cover. Thus, our results show that the lake mixing regime is an important environmental factor that affects the CCC in Lake Tiefer See. Further investigation of the CCC covering longer periods with potentially different lake mixing regimes would be necessary to compare and trace 
possible changes in cyanobacteria dynamics driven by water circulation mode.

\section{Picocyanobacterial Dynamics}

The abundance of the picocyanobacterial Cyanobium and Synechococcus observed in Lake Tiefer See followed a bimodal pattern common in most temperate lakes, it means, a spring or early summer peak and a second peak in late summer or fall (Stockner et al., 2006). The bimodal picocyanobacterial abundance observed in Lake Tiefer See concurs with previous observations in the nearby oligo-mesotrophic Lake Stechlin (Padisák et al., 2003) and/or in large subalpine lakes such as Lake Constance (Gaedke and Weisse, 1998) and Lake Maggiore (Callieri and Piscia, 2002). The peak abundance of ASVs assigned to Synechococcus (in June) and Cyanobium (in October; see Figure 4B) at different water depths throughout the year may be explained by their ability to tolerate and adapt to a variety of light conditions (Gervais et al., 1997; Callieri and Piscia, 2002). Other abiotic factors driving picocyanobacterial variability include nutrient availability (Bell and Kalff, 2001), lake morphometry and thermal regime (i.e., deep lakes with a stable vertical structure promote picocyanobacterial development, Camacho et al., 2009), changes in lake physicochemical factors that promote the coexistence of phycoerythrin- and phycocyaninrich picocyanobacterial groups (Postius and Ernst, 1999; Stomp et al., 2007), and the interplay between ultraviolet and photosynthetically active radiation (Callieri et al., 2001, 2012b). Additionally, variations in picocyanobacterial dynamics could be driven by biotic factors such as grazing by ciliates and protists (Callieri et al., 2002; Jezberová and Komárková, 2007) as well as viral lysis (Personnic et al., 2009). Based on the low Chla values $\left(<20 \mu \mathrm{g} \mathrm{L}^{-1}\right.$ in 2019; Figure 2E) from Lake Tiefer See and thus its oligo-mesotrophic status, we suggest that there is likely an enrichment of phycoerythrin picocyanobacteria population in Lake Tiefer See. This would be in line with a European multilake series investigation comprising deep and shallow lakes which revealed that phycoerythrin-rich picocyanobacteria dominated the water column at low Chla levels (Vörös et al., 1998).

The seasonal and spatial (i.e., water depth) differences in the relative abundances of the Cyanobium ASVs 0005, 0008, and 0014 suggests niche specialization within this genus. The spring epilimnetic peak abundance ( $>40 \%$ ) of Cyanobium ASV0008 suggests that it copes well at $10-15^{\circ} \mathrm{C}$ and it may also contribute substantially to the increase in $\mathrm{pH}$ values (up to 9). This is in line with monitoring reports from Lake Tiefer See that showed the increase in phytoplankton bio-productivity in spring increases the $\mathrm{pH}$ value of the water up to 8.6 (Roeser et al., 2021).

In Lake Tiefer See, the thermal stratification in summer seems to establish a niche for Cyanobium ASV0014 in the hypolimnion $(\sim 15-50 \mathrm{~m})$ because of a high relative abundance (40\%) of this ASV, compared to the upper waters or other seasons where it was generally $\leq 15 \%$. While it has been suggested that temperature plays a key role in initiating picocyanobacterial abundance and growth in freshwater ecosystems (Weisse, 1993; Vörös et al., 2009), its effect on regulating picocyanobacterial dynamics is still unclear (Callieri et al., 2012a). The negative correlation of ASV0014 with temperature suggests that this taxon copes better with lower temperatures in the hypolimnion than other groups. In addition, ASV0014 might utilize the most penetrating green and blue lights in the lower meta- to upper hypolimnion to outcompete other autotrophs and promote its success in the low-light reaching deeper waters in summer (Pick and Agbeti, 1991; Vörös et al., 1998; Callieri et al., 2007). Elsewhere, higher picocyanobacterial abundances have also been reported in the lower meta- to upper hypolimnion in Lake Stechlin (Padisák et al., 2003) and Lakes Huron and Michigan (Fahnenstiel and Carrick, 1992). In October, when thermal gradient diminishes caused by lower temperatures in the water column, ASV0005 became the most abundant Cyanobium ASV. Similar to ASV0014 it is also negatively correlated to temperature albeit insignificant. This means the Cyanobium ASVs 0014 and 0005 may be psychrotolerant (cold-adapted) in nature able to tolerate lower temperatures better than other cyanobacteria groups. Their generally lower relative abundances during periods of warmer water temperature $\left(11-20^{\circ} \mathrm{C}\right)$ poses the assumption that they may be "cold-water-preference" species. Psychrophilic picocyanobacterial taxa have been reported in various aquatic environments ranging from the temperate East China sea (Choi et al., 2013) to polar seas (Tang et al., 1997) and most recently in freshwater Lake Biwa, Japan (Cai et al., 2021). While the psychrotolerant picocyanobacteria observed in other freshwater ecosystems were either from surface water samples (Xu et al., 2015) or in the deeper epilimnion (5 m, Lake Biwa Japan), the Cyanobium ASVs 0014 and 0005 from Lake Tiefer See were also abundant in the meta- and hypolimnion (15$55 \mathrm{~m}$ ). In addition, a further factor that possibly contributed to the increase in abundance of the Cyanobium ASVs 0014 and 0005, is the increase in TDP availability beginning in summer in the hypolimnion with a peak in fall. Also, the sediment re-suspension in the shallower parts of the lake may facilitate the release of phosphorus (Nuhfer et al., 1993). Our data suggest that Cyanobium ASVs 0005 and 0014 may be the main utilizers of this nutrient. Since the cyanobacteria community data from our study are based on relative abundances, the observed hypolimnetic abundance of Cyanobium ASV0014 in summer could also result from a decrease of other ASVs. Nevertheless, even if the other ASVs were only reduced while ASV0014 was "maintained/stable," it still indicates that it is able to cope well with the prevailing ambient conditions in deeper waters.

Altogether, the observed fine-scale spatiotemporal dynamics of the picocyanobacteria is a clear indication for niche separation in the water column of deep temperate hard-water lakes especially of individual taxa within Synechococcus and Cyanobium. Future studies could combine isolation, cultivation and physiological tests as well as metagenomics to get a more complete insight on the picocyanobacterial dynamics we observed here.

\section{Planktothrix Dynamics}

The Planktothrix ASV0006 in Lake Tiefer See showed a peak abundance in the zone of low light intensity $(0.1 \%)$ in the metalimnion which concurs with observations in a number of European lakes such as Lake Pusiano (Legnani et al., 2005), Lake Zürich (Posch et al., 2012), Lake Bourget (Jacquet et al., 2005) 
Lake Stechlin (Dadheech et al., 2014), and Lake Steinsfjorden (Halstvedt et al., 2007). The results from our molecular approach are also substantiated by similar findings based on microscopic (Posch et al., 2012; Selmeczy et al., 2016) and cell count studies (Jacquet et al., 2005; Wentzky et al., 2019). The late summer to fall peak in the relative abundance of Planktothrix in the metalimnion of Lake Tiefer See may be explained by factors such as low light intensity $(0.1 \%)$ sufficient for photosynthesis (Walsby and Schanz, 2002; Walsby et al., 2006), lower temperatures $\left(<10^{\circ} \mathrm{C}\right)$ and buoyancy adjustments in the face of changing light dynamics (Konopka, 1982; Teubner et al., 2003; Walsby et al., 2004). The presence of Planktothrix at all investigated water depths, even at $45 \mathrm{~m}$ depth both during and after thermal stratification, indicates an acclimation to water temperatures as low as $5^{\circ} \mathrm{C}$, thus ensuring their winter survival (Walsby, 2005; Holland and Walsby, 2008; Dokulil and Teubner, 2012).

\section{Deep Chlorophyll Maxima and Metalimnetic Oxygen Minimum}

In Lake Tiefer See, the deep chlorophyll maxima (DCM) formed by Cyanobium ASV0008/Synechococcus (7 m; spring), Cyanobium ASV0005 (7 m; fall), and Planktothrix (10-15 m; spring to fall) probably result from the adaptation of these taxa to both low nutrients and light intensity in the thermocline (Walsby et al., 2004; Callieri et al., 2007). This suggests ecotype and niche specialization as well as coexistence among the DCM-forming taxa in Lake Tiefer See. The coexistence may be explained by their different responses to environmental factors such as light and nutrient $\left(\mathrm{NO}_{3}{ }^{-}\right.$and TDP) availability (Selmeczy et al., 2016). For example, the requirements for different degrees of light intensity might explain the Planktothrix and Synechococcus summer peak relative abundances at $10 \mathrm{~m}$ and $7 \mathrm{~m}$ water depths, respectively. In the nearby Lake Stechlin spatial segregation and coexistence of DCM forming cyanobacteria was reported with Aphanizomenon as a main contributor (Selmeczy et al., 2016). Similar observations of the coexistence and niche specialization among cyanobacterial taxa with red and green pigments along the light gradient were reported for several aquatic ecosystems (Pick and Agbeti, 1991; Vörös et al., 1998; Stomp et al., 2007). The heterotrophic decomposition of the DCM-forming taxa as indicated by the qPCR results would explain consumption of dissolved oxygen (11 and $13 \mathrm{~m}$; Figure 2B) between August and November (Gerphagnon et al., 2015). The development of a metalimnetic oxygen minimum indicates that enhanced particle retention time in this relatively denser region favors heterotrophic decomposition of organic matter (Wentzky et al., 2019; Mi et al., 2020).

\section{CONCLUSION}

This study provides the first detailed seasonal survey of the dynamics of CCC, spatial distribution and abundance in the deep hard-water Lake Tiefer See. Combining high-throughput sequencing and ASV analysis enables to reveal freshwater cyanobacteria dynamics on a high taxonomic resolution and suggests niche separation and coexistence of individual cyanobacterial species. At the same time, the study underlines limitations of purely DNA-based pelagic surveys in providing evidence for potentially novel, cold-adapted cyanobacterial species whose occurrence is suggested here.

\section{DATA AVAILABILITY STATEMENT}

The datasets presented in this study can be found in online repositories. The names of the repository/repositories and accession number(s) can be found below: https://www.ebi.ac.uk/ ena, PRJEB40406, ERS5083566-ERS5083644.

\section{AUTHOR CONTRIBUTIONS}

ECN, AB, ED, and SL: conceptualization. ECN, PR, SL, and $\mathrm{AB}$ : methodology. ECN and SY: software. ECN, SL, and AB: validation. ECN, PR, SP, SY, and LG: formal analysis. ECN, $\mathrm{PR}$, and SP: investigation. ECN, SP, and SY: data curation. ECN and PR: visualization. ECN: manuscript writing with input from all authors. SL: supervision. AB, DW, and SL: project administration.

\section{FUNDING}

We thank the German Environmental Foundation (Deutsche Bundesstiftung Umwelt DBU) for funding the research position of ECN. The monitoring equipment was funded by the Terrestrial Environmental Observatory Infrastructure Initiative of the Helmholtz Association (TERENO Observatory NE Germany). This study was also supported by the Leibniz Association grant SAW-2017-IOW-2 649 "BaltRap: The Baltic Sea and its southern Lowlands: proxy-environment interactions in time of rapid change", and the "Climate signal transfer to varved sediments in Lake Tiefer See Klocksin-Monitoring, Transfer functions, Reconstructions" awarded to AB.

\section{ACKNOWLEDGMENTS}

We thank the technical team of the GFZ Section Climate Dynamics and Landscape Evolution who assisted in the fieldwork, especially Brian Brademann. We thank Jens Kallmeyer (GFZ Section Geomicrobiology) for assisting with nitrate measurements, Olaf Dellwig (IOW - Marine Geology) for assisting with TDP measurements, and Anne Köhler for support in the ICP lab at the IOW. We also want to thank Alexander Bartholomäus (GFZ Section Geomicrobiology) for additional help with bioinformatics and insightful result interpretation that improved the manuscript.

\section{SUPPLEMENTARY MATERIAL}

The Supplementary Material for this article can be found online at: https://www.frontiersin.org/articles/10.3389/fmicb.2021. 761259/full\#supplementary-material 


\section{REFERENCES}

Aho, A. V., Kernighan, B. W., and Weinberger, P. J. (1979). Awk a pattern scanning and processing language. Softw. Pract. Exp. 9, 267-279. doi: 10.1002/ spe. 4380090403

Albrecht, M., Pröschold, T., and Schumann, R. (2017). Identification of cyanobacteria in a eutrophic coastal lagoon on the southern baltic coast. Front. Microbiol. 8:293. doi: 10.3389/fmicb.2017.00923

Allgaier, M., and Grossart, H. P. (2006). Seasonal dynamics and phylogenetic diversity of free living and particle-associated bacterial communities in four lakes in northeastern Germany. Aquat. Microb. Ecol. 45, 115-128. doi: 10.3354/ ame 045115

Andrews, S., Krueger, F., Seconds-Pichon, A., Biggins, F., and Wingett, S. (2015). FastQC. A quality control tool for high throughput sequence data. Babraham Bioinformatics. Cambridge: Babraham Institute.

Bell, T., and Kalff, J. (2001). The contribution of picophytoplankton in marine and freshwater systems of different trophic status and depth. Limnol. Oceanogr. 46, 1243-1248. doi: 10.4319/lo.2001.46.5.1243

Boehrer, B., and Schultze, M. (2008). Stratification of lakes. Rev. Geophys. 46:210. doi: 10.1029/2006RG000210

Bolyen, E., Rideout, J. R., Dillon, M. R., Bokulich, N. A., Abnet, C. C., AlGhalith, G. A., et al. (2019). Reproducible, interactive, scalable and extensible microbiome data science using QIIME 2. Nat. Biotechnol. 37, 852-857. doi: 10.1038/s41587-019-0209-9

Bushnell, B., Rood, J., and Singer, E. (2017). BBTools software package. PLoS One. 12:e0185056. doi: 10.1371/journal.pone.0185056

Bustin, S. A., Benes, V., Garson, J. A., Hellemans, J., Huggett, J., Kubista, M., et al. (2009). The MIQE guidelines: Minimum information for publication of quantitative real-time PCR experiments. Clin. Chem. 55, 611-622. doi: 10.1373/ clinchem.2008.112797

Butts, E., and Carrick, H. J. (2017). Phytoplankton seasonality along a trophic gradient of temperate lakes: convergence in taxonomic composition during winter ice-cover. Northeast Nat. 24, B167-B187. doi: 10.1656/045.024.s719

Cai, J., Hodoki, Y., and Nakano, S. (2021). Phylogenetic diversity of the picocyanobacterial community from a novel winter bloom in Lake Biwa. Limnology 22, 161-167. doi: 10.1007/s10201-020-00649-5

Callahan, B. J., McMurdie, P. J., Rosen, M. J., Han, A. W., Johnson, A. J. A., and Holmes, S. P. (2016). DADA2: High-resolution sample inference from Illumina amplicon data. Nat. Methods 13, 581-583. doi: 10.1038/nmeth.3869

Callieri, C., Caravati, E., Corno, G., and Bertoni, R. (2012a). Picocyanobacterial community structure and space-time dynamics in the subalpine Lake Maggiore (N. Italy). J. Limnol. 63, 244-249. doi: 10.4081/jlimnol.2012.e9

Callieri, C., Corno, G., Caravati, E., Galafassi, S., Bottinelli, M., and Bertoni, R. (2007). Photosynthetic characteristics and diversity of freshwater Synechococcus at two depths during different mixing conditions in a deep oligotrophic lake. J. Limnol. 66, 81-89. doi: 10.4081/jlimnol.2007.81

Callieri, C., Cronberg, G., and Stockner, J. G. (2012b). "Freshwater picocyanobacteria: Single cells, microcolonies and colonial forms," in Ecology of Cyanobacteria II: Their Diversity in Space and Time, ed. B. Whitton (Dordrecht: Springer), 229-269. doi: 10.1007/978-94-007-3855-3_8

Callieri, C., Karjalainen, S. M., and Passoni, S. (2002). Grazing by ciliates and heterotrophic nanoflagellates on picocyanobacteria in Lago Maggiore. Italy. J. Plankton Res. 24, 785-796. doi: 10.1093/plankt/24.8.785

Callieri, C., Morabito, G., Huot, Y., Neale, P. J., and Litchman, E. (2001). Photosynthetic response of pico- and nanoplanktonic algae to UVB, UVA and PAR in a high mountain lake. Aquatic Sci. 63, 286-293. doi: 10.1007/ PL00001355

Callieri, C., and Piscia, R. (2002). Photosynthetic efficiency and seasonality of autotrophic picoplankton in Lago Maggiore after its recovery. Freshw. Biol. 48, 1721-1731. doi: 10.1046/j.1365-2427.2002.00821.x

Callieri, C., and Stockner, J. (2000). Picocyanobacteria success in oligotrophic lakes: Fact or fiction? J. Limnol. 59, 72-76. doi: 10.4081/jlimnol.2000.72

Camacho, A., Picazo, A., Miracle, M. R., and Vicente, E. (2009). Spatial distribution and temporal dynamics of picocyanobacteria in a meromictic karstic lake. Arch. Hydrobiol. Suppl. Algol. Stud. 109, 171-184. doi: 10.1127/1864-1318/ 2003/0109-0171

Caporaso, J. G., Kuczynski, J., Stombaugh, J., Bittinger, K., Bushman, F. D., Costello, E. K., et al. (2010). QIIME allows analysis of high-throughput community sequencing data. Nat. Methods 7, 335-336. doi: 10.1038/nmeth. f.303

Carey, C. C., Ibelings, B. W., Hoffmann, E. P., Hamilton, D. P., and Brookes, J. D. (2012). Eco-physiological adaptations that favour freshwater cyanobacteria in a changing climate. Water Res. 46, 1394-1407. doi: 10.1016/j.watres.2011. 12.016

Choi, D. H., Noh, J. H., and Shim, J. (2013). Seasonal changes in picocyanobacterial diversity as revealed by pyrosequencing in temperate waters of the East China Sea and the East Sea. Aquat. Microb. Ecol. 71, 75-90.

Dadheech, P. K., Selmeczy, G. B., Vasas, G., Pádisak, J., Arp, W., Tapolczai, K., et al. (2014). Presence of potential toxin-producing cyanobacteria in an oligomesotrophic lake in Baltic lake district, Germany: An ecological, Genetic and toxicological survey. Toxins 6, 2912-2931. doi: 10.3390/toxins6102912

Diao, M., Sinnige, R., Kalbitz, K., Huisman, J., and Muyzer, G. (2017). Succession of bacterial communities in a seasonally stratified lake with an anoxic and sulfidic hypolimnion. Front. Microbiol. 8:2511. doi: 10.3389/fmicb.2017.02511

Dokulil, M. T., and Teubner, K. (2012). Deep living Planktothrix rubescens modulated by environmental constraints and climate forcing. Hydrobiologia 161, 185-201. doi: 10.1007/s10750-012-1020-5

Dräger, N., Plessen, B., Kienel, U., Słowiński, M., Ramisch, A., Tjallingii, R., et al. (2019). Hypolimnetic oxygen conditions influence varve preservation and $\delta 13 \mathrm{C}$ of sediment organic matter in Lake Tiefer See. NE Germany J. Paleolimnol. 62, 181-194. doi: 10.1007/s10933-019-00084-2

Dräger, N., Theuerkauf, M., Szeroczyńska, K., Wulf, S., Tjallingii, R., Plessen, B., et al. (2017). Varve microfacies and varve preservation record of climate change and human impact for the last 6000 years at Lake Tiefer See (NE Germany). Holocene 27, 450-464. doi: 10.1177/0959683616660173

Fahnenstiel, G. L., and Carrick, H. J. (1992). Phototrophic picoplankton in Lakes Huron and Michigan: abundance, distribution, composition, and contribution to biomass and production. Can. J. Fish. Aquat. Sci. 43, 235-240. doi: 10.1139/ f92- 043

Gaedke, U., and Weisse, T. (1998). Seasonal and interannual variability of picocyanobacteria in Lake Constance (1987 - 1996). Lake Const. Charact. Ecosyst. Transit. 53, 143-158.

Ger, K. A., Urrutia-Cordero, P., Frost, P. C., Hansson, L. A., Sarnelle, O., Wilson, A. E., et al. (2016). The interaction between cyanobacteria and zooplankton in a more eutrophic world. Harmful Algae 54, 128-144. doi: 10.1016/j.hal.2015. 12.005

Gerphagnon, M., Macarthur, D. J., Latour, D., Gachon, C. M. M., Van Ogtrop, F., Gleason, F. H., et al. (2015). Microbial players involved in the decline of filamentous and colonial cyanobacterial blooms with a focus on fungal parasitism. Environ. Microbiol. 8, 2573-2587. doi: 10.1111/1462-2920.12860

Gervais, F., Padisák, J., and Koschel, R. (1997). Do light quality and low nutrient concentration favor picocyanobacteria below the thermocline of the oligotrophic Lake Stechlin? J. Plankton Res. 19, 771-781. doi: 10.1093/plankt/ 19.6.771

Halstvedt, C. B., Rohrlack, T., Andersen, T., Skulberg, O., and Edvardsen, B. (2007). Seasonal dynamics and depth distribution of Planktothrix spp. in Lake Steinsfjorden (Norway) related to environmental factors. J. Plankton Res. 29, 471-482. doi: 10.1093/plankt/fbm036

Hammer, O., Harper, D. A. T., and Ryan, P. D. (2001). PAST: paleontological statistics software package for education and data analysis. Palaeontol. Electron. 29, 471-482. doi: 10.1016/j.bcp.2008.05.025

Hense, I., and Beckmann, A. (2006). Towards a model of cyanobacteria life cycleeffects of growing and resting stages on bloom formation of N2-fixing species. Ecol. Model. 195, 205-218. doi: 10.1016/j.ecolmodel.2005.11.018

Holland, D. P., and Walsby, A. E. (2008). Viability of the cyanobacterium Planktothrix rubescens in the cold and dark, related to over-winter survival and summer recruitment in Lake Zürich. Eur. J. Phycol. 43, 179-184. doi: 10.1080/09670260801904822

Huisman, J., Codd, G. A., Paerl, H. W., Ibelings, B. W., Verspagen, M. H. J., and Visser, P. M. (2018). Cyanobacterial blooms. Nat. Rev. Microbiol. 16, 471-483. doi: 10.1038/s41579-018-0040-1

Ivanikova, N. V., Popels, L. C., McKay, R. M. L., and Bullerjahn, G. S. (2007). Lake Superior supports novel clusters of cyanobacterial picoplankton. Appl. Environ. Microbiol. 73, 4055-4065. doi: 10.1128/AEM.00214-07

Jacquet, S., Briand, J. F., Leboulanger, C., Avois-Jacquet, C., Oberhaus, L., Tassin, B., et al. (2005). The proliferation of the toxic cyanobacterium Planktothrix 
rubescens following restoration of the largest natural French lake (Lac du Bourget). Harmful Algae 170, 125-132. doi: 10.1016/j.hal.2003.12.006

Janse, I., Meima, M., Kardinaal, W. E. A., and Zwart, G. (2003). High-resolution differentiation of cyanobacteria by using rrna-internal transcribed spacer denaturing gradient gel electrophoresis. Appl. Environ. Microbiol. 69, 66346643. doi: 10.1128/AEM.69.11.6634-6643.2003

Jezberová, J., and Komárková, J. (2007). Morphological transformation in a freshwater Cyanobium sp. induced by grazers. Environ. Microbiol. 9, 1858-1862. doi: $10.1111 / j .1462-2920.2007 .01311 . x$

Jia, Y., Han, G., Wang, C., Guo, P., Jiang, W., Li, X., et al. (2010). The efficacy and mechanisms of fungal suppression of freshwater harmful algal bloom species. J. Hazard Mater. 183, 176-181. doi: 10.1016/j.jhazmat.2010.07.009

Kaiblinger, C., Greisberger, S., Teubner, K., and Dokulil, M. T. (2007). Photosynthetic efficiency as a function of thermal stratification and phytoplankton size structure in an oligotrophic alpine lake. Hydrobiologia 578, 29-36.

Kong, P., Richardson, P., and Hong, C. (2019). Seasonal dynamics of cyanobacteria and eukaryotic phytoplankton in a multiple-reservoir recycling irrigation system. Ecol. Process. 8:37. doi: 10.1186/s13717-019-0191-7

Konopka, A. (1982). Physiological ecology of a metalimnetic Oscillatoria rubescens population. Limnol. Oceanogr. 23, 10-25. doi: 10.4319/lo.1982.27.6.1154

Kurmayer, R., Sivonen, K., Wilmotte, A., and Salmaso, N. (2017). Molecular Tools for the Detection and Quantification of Toxigenic Cyanobacteria, First Edition. Hoboken, NJ: John Wiley \& Sons Ltd.

Legendre, P., Borcard, D., and Peres-Neto, P. R. (2005). Analyzing beta diversity: Partitioning the spatial variation of community composition data. Ecol. Monogr. 75, 435-450. doi: 10.1890/05-0549

Legendre, P., and Gallagher, E. D. (2001). Ecologically meaningful transformations for ordination of species data. Oecologia 129, 271-280. doi: 10.1007/ s004420100716

Legnani, E., Copetti, D., Oggioni, A., Tartari, G., Palumbo, M. T., and Morabito, G. (2005). Planktothrix rubescens' seasonal dynamics and vertical distribution in Lake Pusiano (North Italy). J. Limnol. 47, 1656-1663. doi: 10.4081/jlimnol. 2005.61

Mazard, S., Penesyan, A., Ostrowski, M., Paulsen, I. T., and Egan, S. (2016). Tiny microbes with a big impact: The role of cyanobacteria and their metabolites in shaping our future. Mar. Drugs 14:97. doi: 10.3390/md14050097

Mi, C., Shatwell, T., Ma, J., Wentzky, V. C., Boehrer, B., Xu, Y., et al. (2020). The formation of a metalimnetic oxygen minimum exemplifies how ecosystem dynamics shape biogeochemical processes: A modelling study. Water Res. 175:115701. doi: 10.1016/j.watres.2020.115701

Monchamp, M. E., Spaak, P., Domaizon, I., Dubois, N., Bouffard, D., and Pomati, F. (2018). Homogenization of lake cyanobacterial communities over a century of climate change and eutrophication. Nat. Ecol. Evol. 2, 317-324. doi: 10.1038/ s41559-017-0407-0

Nitin Parulekar, N., Kolekar, P., Jenkins, A., Kleiven, S., Utkilen, H., Johansen, A., et al. (2017). Characterization of bacterial community associated with phytoplankton bloom in a eutrophic lake in South Norway using $16 \mathrm{~S}$ rRNA gene amplicon sequence analysis. PLoS One. 12:e0173408. doi: 10.1371/journal. pone. 0173408

Nübel, U., Garcia-Pichel, F., and Muyzer, G. (1997). PCR primers to amplify $16 S$ rRNA genes from cyanobacteria. Appl. Environ. Microbiol. 63, 3327-3332.

Nuhfer, E. B., Anderson, R. Y., Bradbury, J. P., and Dean, W. E. (1993). Modern sedimentation in Elk lake, clearwater county, minnesota. Spec. Pap. Geol. Soc. Am. 276, 1-6. doi: 10.1130/SPE276-p75

Nwosu, E. C., Brauer, A., Kaiser, J., Horn, F., Wagner, D., and Liebner, S. (2021a). Evaluating sedimentary DNA for tracing changes in cyanobacteria dynamics from sediments spanning the last 350 years of Lake Tiefer See, NE Germany. J. Paleolimnol. 2021:2069. doi: 10.1007/s10933-021-00206-9

Nwosu, E. C., Roeser, P., Yang, S., Ganzert, L., Dellwig, O., Pinkerneil, S., et al. (2021b). From Water into sediment-tracing freshwater cyanobacteria via DNA Analyses. Microorganisms 2021:9081778. doi: 10.3390/microorganisms908 1778

Okazaki, Y., and Nakano, S. I. (2016). Vertical partitioning of freshwater bacterioplankton community in a deep mesotrophic lake with a fully oxygenated hypolimnion (Lake Biwa, Japan). Environ. Microbiol. Rep. 8, 780788. doi: 10.1111/1758-2229.12439

Oksanen, J., Blanchet, F. G., Friendly, M., Kindt, R., Legendre, P., McGlinn, D., et al. (2019). vegan: Community Ecology Package. R package version 2.5-2.
Padisák, J., Barbosa, F., Koschel, R., and Krienitz, L. (2003). Deep layer cyanoprokaryota maxima in temperate and tropical lakes. Adv. Limnol. 24, 1363-1366.

Paerl, H. W., and Huisman, J. (2008). Blooms like it hot. Science 320, 57-58. doi: $10.1126 /$ science. 1155398

Personnic, S., Domaizon, I., Sime-Ngando, T., and Jacquet, S. (2009). Seasonal variations of microbial abundances and virus- versus flagellate-induced mortality of picoplankton in three peri-alpine lakes. J. Plankton Res. 31, 11611177. doi: $10.1093 /$ plankt/fbp057

Pick, F. R., and Agbeti, D. M. (1991). The seasonal dynamic and composition of photosynthetic picoplankton communities in temperate lakes in Ontario, Canada. Int. Rev. Ges. Hydrobio. 76, 565-580. doi: 10.1002/iroh.19910760409

Posch, T., Köster, O., Salcher, M. M., and Pernthaler, J. (2012). Harmful filamentous cyanobacteria favoured by reduced water turnover with lake warming. Nat. Clim. Chang. 2, 809-813. doi: 10.1038/nclimate1581

Postius, C., and Ernst, A. (1999). Mechanisms of dominance: Coexistence of picocyanobacterial genotypes in a freshwater ecosystem. Arch. Microbiol. 172, 69-75. doi: 10.1007/s002030050742

Quast, C., Pruesse, E., Yilmaz, P., Gerken, J., Schweer, T., Yarza, P., et al. (2013). The SILVA ribosomal RNA gene database project: Improved data processing and web-based tools. Nucleic Acids Res. 41, 590-596. doi: 10.1093/nar/ gks1219

Reynolds, C. S., Oliver, R. L., and Walsby, A. E. (1987). Cyanobacterial dominance: The role of buoyancy regulation in dynamic lake environments. New Zeal. J. Mar. Freshw. Res. 21, 379-390. doi: 10.1080/00288330.1987.9516234

Richardson, J., Miller, C., Maberly, S. C., Taylor, P., Globevnik, L., Hunter, et al. (2018). Effects of multiple stressors on cyanobacteria abundance vary with lake type. Glob. Chang. 24, 5044-5055. doi: 10.1111/gcb.14396

Roeser, P., Drager, N., Brykała, D., Ott, F., Pinkerneil, S., Gierszewski, P., et al. (2021). Advances in understanding calcite varve formation: new insights from a dual lake monitoring approach in the southern Baltic lowlands. Boreas 2021:12506. doi: 10.1111/bor.12506

Saary, P., Forslund, K., Bork, P., and Hildebrand, F. (2017). RTK: efficient rarefaction analysis of large datasets. Bioinformatics 33, 2594-2595. doi: 10. 1093/bioinformatics/btx206

Salmaso, N., Albanese, D., Capelli, C., Boscaini, A., Pindo, M., and Donati, C. (2018). Diversity and cyclical seasonal transitions in the bacterial community in a large and deep perialpine lake. Microb. Ecol. 76, 125-143. doi: 10.1007/s00248017-1120-x

Salmaso, N., Capelli, C., Shams, S., and Cerasino, L. (2015). Expansion of bloom-forming Dolichospermum lemmermannii (Nostocales, Cyanobacteria) to the deep lakes south of the Alps: Colonization patterns, driving forces and implications for water use. Harmful Algae 50, 76-87. doi: 10.1016/j.hal.2015. 09.008

Savichtcheva, O., Debroas, D., Kurmayer, R., Villar, C., Jenny, J. P., Arnaud, F., et al. (2011). Quantitative PCR enumeration of total/toxic Planktothrix rubescens and total cyanobacteria in preserved DNA isolated from lake sediments. Appl. Environ. Microbiol. 77, 8744-8753. doi: 10.1128/AEM.06106-11

Schloss, P. D., Westcott, S. L., Ryabin, T., Hall, J. R., Hartmann, M., Hollister, E. B., et al. (2009). Introducing mothur: Open-source, platform-independent, community-supported software for describing and comparing microbial communities. Appl. Environ. Microbiol. 75, 7537-7541. doi: 10.1128/AEM. 01541-09

Schweitzer-Natan, O., Ofek-Lalzar, M., Sher, D., and Sukenik, A. (2019). Particleassociated microbial community in a subtropical lake during thermal mixing and phytoplankton succession. Front. Microbiol. 10:2142. doi: 10.3389/fmicb. 2019.02142

Selmeczy, G. B., Tapolczai, K., Casper, P., Krienitz, L., and Padisak, J. (2016). Spatial- and niche segregation of DCM-forming cyanobacteria in Lake Stechlin (Germany). Hydrobiologia 764, 229-240. doi: 10.1007/s10750-015-2282-5

Smilauer, P., and Leps, J. (2014). Multivariate analysis of ecological data using Canoco 5. Cambridge: Cambridge University Press, doi: 10.1017/ СBO9781139627061

Soule, T., and Garcia-Pichel, F. (2019). "Cyanobacteria," in Encyclopedia of Microbiology. Amsterdam: Elsevier, 799-817. doi: 10.1016/B978-0-12-8096338.20886-8

Stockner, J., Callieri, C., and Cronberg, G. (2006). Picoplankton and other nonbloom- forming cyanobacteria in lakes. Ecol. Cyanobac. 42, 1300-1311. doi: 10.1007/0-306-46855-7_7 
Stomp, M., Huisman, J., Vörös, L., Pick, F. R., Laamanen, M., Haverkamp, T., et al. (2007). Colourful coexistence of red and green picocyanobacteria in lakes and seas. Ecol. Lett. 10, 290-298. doi: 10.1111/j.1461-0248.2007.01 026.x

Sukenik, A., Quesada, A., and Salmaso, N. (2015). Global expansion of toxic and non-toxic cyanobacteria: effect on ecosystem functioning. Biodivers. Conserv. 24, 889-908. doi: 10.1007/s10531-015-0905-9

Tang, E. P. Y., Tremblay, R., and Vincent, W. F. (1997). Cyanobacteria dominance of polar freshwater ecosystems: are high latitude mat-formers adapted to low temperature? J. Phycol. 33, 171-181. doi: 10.1111/j.0022-3646.1997.00 171.x

Teubner, K., Tolotti, M., Greisberger, S., Morscheid, H., Dokulil, M. T., and Morscheid, H. (2003). Steady state phytoplankton in a deep pre-alpine lake: Species and pigments of epilimnetic versus metalimnetic assemblages. Hydrobiologia 502, 49-64. doi: 10.1023/B:HYDR.0000004269.54705.cb

Theuerkauf, M., Dräger, N., Kienel, U., Kuparinen, A., and Brauer, A. (2015). Effects of changes in land management practices on pollen productivity of open vegetation during the last century derived from varved lake sediments. Holocene 25, 733-744. doi: 10.1177/0959683614567881

Urrutia-Cordero, P., Ekvall, M. K., and Hansson, L. A. (2016). Controlling harmful cyanobacteria: Taxa-specific responses of cyanobacteria to grazing by largebodied Daphnia in a biomanipulation scenario. PLoS One. 11:e0153032. doi: 10.1371/journal.pone.0153032

Větrovský, T., and Baldrian, P. (2013). The Variability of the 16S rRNA gene in bacterial genomes and its consequences for bacterial community analyses. PLoS One 8:e57923. doi: 10.1371/journal.pone.0057923

Visser, P. M., Verspagen, J. M. H., Sandrini, G., Stal, L. J., Matthijs, H. C. P., Paerl, H. W., et al. (2016). How rising CO2 and global warming may stimulate harmful cyanobacterial blooms. Harmful Algae 54, 145-159. doi: 10.1016/j.hal.2015.12.006

Vörös, L., Callieri, C., V-Balogh, K., and Bertoni, R. (1998). Freshwater picocyanobacteria along a trophic gradient and light quality range. Hydrobiologia 369, 117-125. doi: 10.1007/978-94-017-2668-9_10

Vörös, L., Mózes, A., and Somogyi, B. (2009). A five-year study of autotrophic winter picoplankton in Lake Balaton. Hungary. Aquat. Ecol. 43, 727-734. doi: 10.1007/s10452-009-9272-5

Wagner, C., and Adrian, R. (2009). Cyanobacteria dominance: Quantifying the effects of climate change. Limnol. Oceanogr. 54, 2460-2468. doi: 10.4319/lo. 2009.54.6_part_2.2460

Walsby, A. E. (2005). Stratification by cyanobacteria in lakes: A dynamic buoyancy model indicates size limitations met by Planktothrix rubescens filaments. New Phytol. 168, 365-376. doi: 10.1111/j.1469-8137.2005.01 508.x
Walsby, A. E., Ng, G., Dunn, C., and Davis, P. A. (2004). Comparison of the depth where Planktothrix rubescens stratifies and the depth where the daily insolation supports its neutral buoyancy. New Phytol. 162, 133-145. doi: 10.1111/j.14698137.2004.01020.x

Walsby, A. E., and Schanz, F. (2002). Light-dependent growth rate determines changes in the population of Planktothrix rubescens over the annual cycle in lake Zürich. Switzerla. New Phytol. 154, 671-687. doi: 10.1046/j.1469-8137.2002. 00401.x

Walsby, A. E., Schanz, F., and Schmid, M. (2006). The Burgundy-blood phenomenon: A model of buoyancy change explains autumnal waterblooms by Planktothrix rubescens in Lake Zürich. New Phytol. 169, 109-122. doi: 10.1111/ j.1469-8137.2005.01567.x

Weisse, T. (1993). Dynamics of autotrophic picoplankton in marine and freshwater ecosystems. Adv. Microbial. Ecol. 13, 327-370. doi: 10.1007/978-1-4615-28586_8

Wentzky, V. C., Frassl, M. A., Rinke, K., and Boehrer, B. (2019). Metalimnetic oxygen minimum and the presence of Planktothrix rubescens in a low-nutrient drinking water reservoir. Water Res. 148, 208-218. doi: 10.1016/j.watres.2018. 10.047

Winder, M., Reuter, J. E., and Schladow, S. G. (2009). Lake warming favours small-sized planktonic diatom species. Proc. R. Soc. B Biol. Sci. 276, 427-435. doi: $10.1098 /$ rspb.2008.1200

$\mathrm{Xu}$, Y., Jiao, N., and Chen, F. (2015). Novel psychrotolerant picocyanobacteria isolated from Chesapeake Bay in the winter. J. Phycol. 51, 782-790. doi: 10.1111/ jpy. 12318

Conflict of Interest: The authors declare that the research was conducted in the absence of any commercial or financial relationships that could be construed as a potential conflict of interest.

Publisher's Note: All claims expressed in this article are solely those of the authors and do not necessarily represent those of their affiliated organizations, or those of the publisher, the editors and the reviewers. Any product that may be evaluated in this article, or claim that may be made by its manufacturer, is not guaranteed or endorsed by the publisher.

Copyright (C) 2021 Nwosu, Roeser, Yang, Pinkerneil, Ganzert, Dittmann, Brauer, Wagner and Liebner. This is an open-access article distributed under the terms of the Creative Commons Attribution License (CC BY). The use, distribution or reproduction in other forums is permitted, provided the original author(s) and the copyright owner(s) are credited and that the original publication in this journal is cited, in accordance with accepted academic practice. No use, distribution or reproduction is permitted which does not comply with these terms. 